\title{
Current and Future Trends in Strength and Conditioning for Female Athletes
}

\author{
Anthony C. Santos, Tristan J. Turner and Dierdra K. Bycura *
}

check for updates

Citation: Santos, A.C.; Turner, T.J.; Bycura, D.K. Current and Future Trends in Strength and Conditioning for Female Athletes. Int. J. Environ. Res. Public Health 2022, 19, 2687. https://doi.org/10.3390/ ijerph19052687

Academic Editor: Corrado Lupo

Received: 16 December 2021

Accepted: 22 February 2022

Published: 25 February 2022

Publisher's Note: MDPI stays neutral with regard to jurisdictional claims in published maps and institutional affiliations.

Copyright: (C) 2022 by the authors. Licensee MDPI, Basel, Switzerland. This article is an open access article distributed under the terms and conditions of the Creative Commons Attribution (CC BY) license (https:// creativecommons.org/licenses/by/ $4.0 /)$.

\author{
Department of Health Sciences, Northern Arizona University, Flagstaff, AZ 86011, USA; \\ anthony.santos@nau.edu (A.C.S.); tjt348@nau.edu (T.J.T.) \\ * Correspondence: dierdra.bycura@nau.edu
}

\begin{abstract}
Participation by female athletes in competitive sport has increased dramatically since the inception of Title IX, although female athletes are represented significantly less than their male counterparts in strength and conditioning $(S \& C)$ literature. This is apparent when examining current identified trends in the field, such as implementation of blood flow restriction (BFR) training, functional assessments to predict injuries, or the ever-increasing use of technology in sports. The aim of this review is to examine three prevalent trends in contemporary S\&C literature as they relate to female athletes in order to expose areas lacking in research. We conducted journal and database searches to progressively deepen our examination of available research, starting first with broad emerging themes within $S \& C$, followed next by an inquiry into literature concerning $S \& C$ practices in females, ending finally with a review of emerging topics concerning female athletes. To this end, 534 articles were reviewed from PubMed, Academic Search Complete, Google Scholar, CINAHL, MEDLINE, and Web of Science. Results demonstrate the utility of implementing BFR, functional movement assessments, and various technologies among this population to expand representation of female athletes in S\&C literature, improve athletic capabilities and performance, and decrease potential for injury over time.
\end{abstract}

Keywords: women athletes; training; functional movement; blood flow restriction; injury prevention; screening; technology

\section{Introduction}

Incorporating female athletes into strength and conditioning (S\&C) programs is relatively new due in part to the passage of Title IX in 1972. Title IX, a federal civil law, had a large impact on females in many different areas within educational institutions, although it arguably had the largest impact on sports participation [1]. Prior to the passage of Title IX, females did participate in sport, but their participation in S\&C was far less than their male counterparts. Female athletes participating in sports prior to 1972 often engaged in more recreation-oriented activities, and few female athletes participated in a competitive environment. Unfortunately, cultural views during the early to mid-20th century did not favor elite performances among female athletes, and therefore female participation in S\&C was viewed as unnecessary [2].

Title IX was certainly a catalyst for a large increase in the number of female athletes in sport at the professional and international levels [3]. The 1900 Olympic Games in Paris saw the first inclusion of female athletes with roughly $2.2 \%$ of females representing the total number of athletes at the Games (i.e., 22 females out of 997 total participants). In contrast, the 2012 Olympic Games in London showcased female athletes competing in every sport offered at the Games. The rise in female participation in the Olympic Games has grown immensely from its inception to a total of $45 \%$ of all participants in the 2016 Olympic Games in Rio de Janeiro [4].

Despite the growth in the participation of female athletes in sport, it seems that growth in S\&C programs for female athletes moves at a slower pace. For example, 50\% 
of high school coaches for male varsity student-athletes required their student-athletes to engage in strength training, compared to only $9 \%$ of coaches of female athletes [5]. To compound the issue further, there is a scarcity of published research focused on females. The average percentage of female participant inclusion per article within the sports and exercise medicine literature is between 35 and 37\% [6]. It is possible that the historical lack of female participation in sport may contribute to this paucity of data, even as the rate of female participation has increased over the years. For example, blood flow restriction (BFR) as a training mechanism is a relatively new training method that is gaining popularity in S\&C and rehabilitative settings. Inclusion of female participants in BFR studies is reported at $14 \%$ and $17 \%$ in studies of acute and chronic use, respectively [7], but only when searches are expanded to include recreationally active or untrained females outside of the 19-44-year-old age range (see Table below). Additionally, other trending areas of inquiry in $\mathrm{S} \& \mathrm{C}$, such as functional assessments and wearable technology, also indicated a lack of studies that included female athletes as compared to their male counterparts.

The National Strength and Conditioning Association (NSCA) was founded in 1978 and is one of the first organizations to provide a certification for strength and conditioning coaches. In 1989, the NSCA released a position statement focusing on strength training for female athletes. Within the NSCA's 1989 position statement, the organization stressed the importance of female role models in S\&C as coaches [7]. A survey of 103 collegiate Division I head S\&C coaches in 1990 found that $99 \%$ of head S\&C coaches were male. Furthermore, the mean ratio of collegiate $S \& C$ staff was 2.6 males to 0.25 females at that time [8]. In 2016, $32 \%$ of all collegiate Division I (DI) S\&C coaching positions were occupied by female S\&C coaches [9]. However, DI male student-athletes reported being less comfortable with a female $S \& C$ coach, and would prefer working with a male $S \& C$ coach over a female $S \& C$ coach regardless of their qualifications [10]. Clearly, while there has been growth in the field of $S \& C$ for both female coaches and athletes, there are still attitudes towards females in $\mathrm{S} \& \mathrm{C}$ that may hinder their development. Addressing the social and structural determinants for females in S\&C should help increase opportunities for both female athletes and coaches.

Given the increasing female participation in sports, there is a need to examine the implementation of current $S \& C$ practices in this population. The overarching goal of this narrative review is to identify the effects of emerging $S \& C$ training modalities on female athletes' performance. More specifically, this narrative review synthesizes available literature regarding three identified prevalent trends in S\&C (i.e., BFR training, functional assessments and screening, and the use of technology in sports) and the utilization of these trends with female athletes in order to guide future research for females participating in sports.

\section{Methods}

To prepare for the narrative review, a preliminary literature search for recent articles on training modalities employed among female athletes was conducted. Initially, we targeted two specific journals in which research of this nature is generally published in order to identify trends in the field of S\&C in female athletes; namely, Medicine \& Science in Sports \& Exercise (MSSE) and the Journal of Strength and Conditioning Research (JSCR). Search criteria regarding publication date included articles that were published in the past eight years; this is the most distal time interval available on each journal's Advanced Search Builder [11,12]. This broad initial search revealed approximately 2000 results. Three topics were then selected based on their prevalence in these peer-reviewed publications (see Table 1 for search result frequencies): blood flow restriction training, functional assessment and screening, and the use of technology in sports. After these topics were established, search terms for female subjects were added to further explore emerging S\&C practices in females. Finally, a search term targeting practices with female athletes was added to specify this group as the focus of this review. Values presented in Table 1 are valid as of December 2021. 
Table 1. Initial literature and database search strategies.

\begin{tabular}{|c|c|c|}
\hline \multicolumn{3}{|c|}{ Literature Search Strategies $^{\text {a }}$} \\
\hline Journal & Search Terms & Results (n) \\
\hline \multirow{6}{*}{ MSSE } & Blood flow restriction training & 184 \\
\hline & $\begin{array}{l}\text { (female OR women) AND blood flow } \\
\text { restriction training }\end{array}$ & 70 \\
\hline & (female OR women) AND athlete* AND & 13 \\
\hline & blood flow restriction training & 13 \\
\hline & Functional assessment AND screening & 188 \\
\hline & $\begin{array}{c}\text { (female OR women) AND functional } \\
\text { assessment AND screening }\end{array}$ & 126 \\
\hline \multirow{13}{*}{ JSCR } & $\begin{array}{l}\text { (female OR women) AND athlete* AND } \\
\text { functional assessment AND screening }\end{array}$ & 63 \\
\hline & Technology in Sports & 470 \\
\hline & $\begin{array}{l}\text { (female OR women) AND technology } \\
\text { in sports }\end{array}$ & 378 \\
\hline & $\begin{array}{c}\text { (female OR women) AND athlete* AND } \\
\text { technology in sports }\end{array}$ & 153 \\
\hline & Blood flow restriction training & 93 \\
\hline & $\begin{array}{l}\text { (female OR women) AND blood flow } \\
\text { restriction training }\end{array}$ & 44 \\
\hline & $\begin{array}{l}\text { (female OR women) AND athlete* AND } \\
\text { blood flow restriction training }\end{array}$ & 33 \\
\hline & Functional assessment AND screening & 168 \\
\hline & $\begin{array}{l}\text { (female OR women) AND functional } \\
\text { assessment AND screening }\end{array}$ & 113 \\
\hline & $\begin{array}{l}\text { (female OR women) AND athlete* AND } \\
\text { functional assessment AND screening }\end{array}$ & 87 \\
\hline & Technology in Sports & 580 \\
\hline & $\begin{array}{l}\text { (female OR women) AND technology } \\
\text { in sports }\end{array}$ & 323 \\
\hline & $\begin{array}{c}\text { (female OR women) AND athlete* AND } \\
\text { technology in sports }\end{array}$ & 285 \\
\hline
\end{tabular}

Academic Database Search Strategies

\begin{tabular}{cc}
\hline Database & Search Terms ${ }^{\text {b }}$ \\
\hline PubMed & \\
Google Scholar & ("female" OR women) AND \\
& $\begin{array}{c}\text { athlete* AND ("strength and } \\
\text { conditioning") AND ("blood } \\
\text { flow restriction training" OR } \\
\text { functional (assessment OR } \\
\text { EBSCOHost c }\end{array}$ \\
& screening) OR technology \\
& OR sports)
\end{tabular}

Web of Science

\section{Filters Applied}

Free full text, Full text, Humans, English, Adult: 19-44 years, Female, from 2011-2021.

Custom date range: 2011-2021. Sort by relevance. Articles: any type. Include citations.

Full Text; Scholarly (Peer Reviewed) Journals; Published Date:

1 January 2011-31 December 2021; Language: English; English Language; Human; Sex: Female; Age Groups: Adult: 19-44 years; English Language; Human; Sex: Female; Age Related: Adult: 19-44 years. Expanders-Apply related words; Apply equivalent subjects. Search modes-Boolean/Phrase. Timespan: 1 January 2011 to 31 December 2021 (Index Date). Languages: English.

Note. JSCR: Journal of Strength and Conditioning Research; MSSE: Medicine \& Science in Sport \& Exercise. " "Articles" were selected for Content Type while "Last 8 Years" was selected for Publication Date for both journals. ${ }^{b}$ Search terms were applied to all fields during database searches. ${ }^{c}$ Academic Search Complete, CINAHL Plus, and MEDLINE were accessed via EBSCOHost at Northern Arizona University.

A database search of the three trending $S \& C$ topics in female athletes was then conducted using PubMed, Google Scholar, EBSCOHost (Academic Search Complete, CINAHL Plus, and MEDLINE via Northern Arizona University's Cline Library), and Web of Science. Search terms and filters utilized are described in Table 1. An emphasis was placed on gathering publications regarding adult female athletes, between the ages of 19 and 44 years, who were a part of a professional, national, major regional, or collegiate organization. Other inclusion criteria included full-text availability, peer-reviewed journal article (excluding 
review articles or dissertations, for instance), and English language (see Figure 1 for full criteria). Articles were excluded based on lacking focus on female athletes, inclusion of untrained or recreationally athletic participants, publication date earlier than 2011, and lack of relevance toward any of the trending topics chosen for review. Records were screened for duplicates and 534 publications were processed overall.

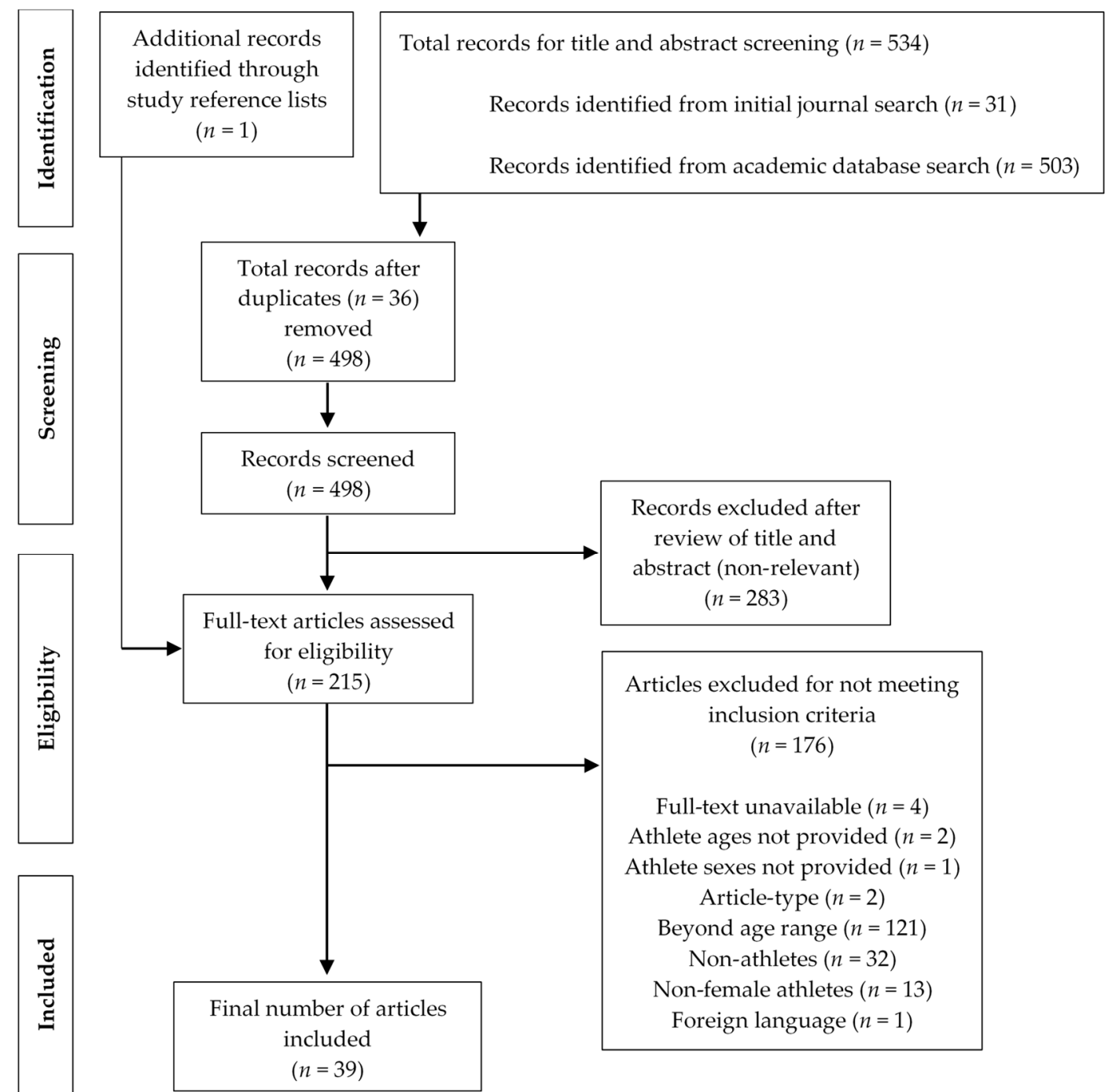

Figure 1. Flowchart of study selection.

\section{Blood Flow Restriction Training}

BFR training is used in both S\&C and rehabilitative settings. BFR aims to occlude venous return to the heart while allowing some arterial blood flow to the occluded area [13]. The reduction of arterial blood flow causes an ischemic state within the muscles. By further eliminating venous return to the heart, BFR forces swelling in the muscle distal to the cuff placement. The reduction of arterial blood flow, ischemic state, and occlusion of venous return increase the metabolic stress within the working muscles and lead to swelling of the muscle cells [14].

Therefore, occlusion pressure, or cuff pressure, is an important factor to consider when using BFR. Many research studies use a protocol of measuring arterial occlusion pressure (in mmHg) using an ultrasound Doppler probe. Cuff pressure is then inflated on the individual at $50-80 \%$ of the pressure required for complete arterial occlusion. It is important to recognize that arterial occlusion pressure values vary from person to person and thus arterial occlusion pressure should be tailored to the individual female athlete. 
Cuff placement is another important factor to consider when implementing BFR. Research protocols in the available literature typically place the cuff on the proximal portion of the limb, most commonly on the proximal thigh or arm. Proximal placement of the BFR cuff can affect distal muscle groups similarly to proximal muscle groups. BFR has been studied with both unilateral and bilateral cuff placement. Unilateral use of BFR has shown improvements on the contralateral limb that are similar to the improvements on the ipsilateral limb. This crossover effect suggests that results from the use of BFR may be systemic [15].

Various types of cuffs may be used in BFR, ranging from elastic bands to inflatable cuffs. Researchers have used a variety of different products in the implementation and study of BFR, though most available literature on females uses a system with an inflatable cuff that monitors and adjusts occlusion pressure during movements throughout the duration of the intervention session.

Although BFR was used as far back as 1983 by the general public, it has more recently been adopted in clinical settings. Yoshiaki Sato was a pioneer in the development of BFR training through the use of the KAATSU training method in Japan, first beginning in 1966 with self-experimentation [16]. Initial publications surrounding BFR have examined a predominantly male study population. The most widely cited reason for the exclusion of females in BFR studies is due to the menstrual cycle (MC) [17]. Few recent studies have sought to bridge the knowledge gap on the effects of BFR throughout the MC. One of the first studies to evaluate the hemodynamic effects of BFR training in untrained females during phases of the $\mathrm{MC}$ highlighted the need for future research examining the relationship between BFR and the MC [18].

The effects of BFR training on females are becoming increasingly better known, though use of female study populations remains relatively low. Studies focusing on females and BFR training have utilized objective measurements including the hemodynamic response to BFR training, aerobic effects (e.g., effects on $\mathrm{VO}_{2 \mathrm{max}}$ ), and anaerobic effects (e.g., effects on muscular power), muscular strength, and muscular hypertrophy. Furthermore, studies have also analyzed subjective measurements such as soreness and ratings of perceived exertion (RPE). Effects of BFR training have been analyzed using various levels of intensities, length of interventions, disease status, age, and more.

Hemodynamic responses to BFR have been measured using heart rate, cardiac output, and stroke volume. Low-load resistance training (RT) with BFR among older females has been shown to result in similar heart rate response and myocardial workload as high-load RT without BFR [19]. Among college-aged females, the use of BFR combined with low-load RT resulted in similar growth hormone and cortisol responses when compared to high-load RT without BFR [20]. Oxygen saturation rates $\left(\mathrm{SpO}_{2}\right)$ are not significantly different when using BFR in low-load RT when compared to low-load and high-load RT without BFR [18]. The occlusion of blood that occurs is a key component of BFR, and may be responsible for the decreased amount of oxygen that is transported throughout the bloodstream, and is therefore available to muscles [21].

Table 2 provides a summary of selected BFR studies published between 2011 and 2021 . Published research regarding the use of BFR in female athlete populations between 19 and 44 years of age is rare. It should be noted that, while the search strategies in this review followed strict guidelines for inclusion and exclusion of studies, criteria were relaxed here as the database searches only yielded three relevant articles. The table and discussion below are thus mostly populated by recreationally active and/or college-aged females, rather than dedicated female athletes. 
Table 2. Summary of blood flow restriction studies among female athletes (2011-2021).

\begin{tabular}{|c|c|c|c|c|}
\hline $\begin{array}{c}\text { Study } \\
\text { [Reference] }\end{array}$ & Participants & Exercise Protocol & Cuff Pressure & Conclusions \\
\hline Amani-Shalamzari et al., 2019 [22] & $\begin{array}{l}32 \text { active collegiate females aged } \\
18-30 \text { years. }\end{array}$ & $\begin{array}{c}\text { Exercise: } 12 \text { sessions of } 2 \text { min } \\
\text { treadmill run } \mathrm{w} / \mathrm{BFR} \text {. Four groups } \\
\text { with varying pressures (increasing } \\
\text { or constant) and exercise intensity } \\
\text { (increasing or constant). }\end{array}$ & $\begin{array}{l}\text { Pressure varied by group. } \\
\text { Min. pressure: } 160 \mathrm{mmHg} \text {. } \\
\text { Max. pressure: } \\
240 \mathrm{mmHg} \text {. }\end{array}$ & $\begin{array}{l}\mathrm{VO}_{2 \max } \text { and anaerobic parameters } \\
\text { increased in all groups. Constant } \\
\text { complete pressure of } 240 \mathrm{mmHg} \\
\text { with increasing exercise intensity } \\
\text { showed the greatest gain in } \\
\text { muscular strength. }\end{array}$ \\
\hline Araujo et al., 2017 [23] & $\begin{array}{l}29 \text { untrained females aged } \\
19-39 \text { years. }\end{array}$ & $\begin{array}{c}\text { Exercises: biceps curl, knee } \\
\text { extension. } \\
\text { LL } 2 \text { BFR: } 1 \times 30,3 \times 15 \\
20 \% 1-\mathrm{RM} \\
\text { HI: } 4 \times 8 \\
80 \% 1 \text {-RM } \\
\text { Control-ADL's } \\
\text { 2/week }\end{array}$ & $\begin{array}{l}80 \% \text { of complete arterial occlusion } \\
\text { at rest. }\end{array}$ & $\begin{array}{l}\text { No significant increase in } \\
\text { flexibility for all groups. HI and } \\
\text { LL }_{\text {BFR had significant increase in }} \\
\text { maximal dynamic strength in } \\
\text { different phases of the MC. }\end{array}$ \\
\hline Centner et al., 2020 [24] & $\begin{array}{l}50 \text { recreationally active females } \\
\text { aged } 18-40 \text { years. }\end{array}$ & $\begin{array}{c}\text { Exercises: squat, isometric squat at } \\
120^{\circ} \text {. Plantar flexion, isometric } \\
\text { plantar flexion at end range. } \\
\text { Vibration frequency: } 30 \mathrm{~Hz} \\
\text { Amplitude: ramping between } \\
2-4 \mathrm{~mm} \\
\text { Dynamic: } 3 \times 15 \text {. } \\
\text { Isometric: } 3 \times 45 \mathrm{~s} \text {. } \\
10 \text { weeks } \times 3 / \text { week }\end{array}$ & $50 \%$ arterial occlusion pressure. & $\begin{array}{c}\text { Whole-body vibration + BFR } \\
\text { increased vastus lateralis CSA } \\
\text { from } 17.4 \pm 2.2 \mathrm{~cm}^{2} \text { to } \\
18.3 \pm 2.3 \mathrm{~cm}^{2} . \text { Comparatively, } \\
\text { whole body vibration training } \\
\text { increased vastus lateralis CSA } \\
\text { from } 19.2 \pm 3.0 \mathrm{~cm}^{2} \text { to } \\
19.5 \pm 2.6 \mathrm{~cm}^{2} .\end{array}$ \\
\hline Kim et al., 2014 [20] & $\begin{array}{l}13 \text { recreationally active females } \\
\text { aged } 18-25 \text { years. }\end{array}$ & $\begin{array}{l}\text { Exercises: } 2 \text { sessions of isotonic } \\
\text { knee extension and leg press. } \\
\text { LL }_{\text {BFR }}: 1 \times 30,2 \times 1520 \% 1-\mathrm{RM} \\
\text { HL-3 } 3 \times 10,80 \% 1-\mathrm{RM}\end{array}$ & $200 \mathrm{mmHg}$. & $\begin{array}{l}\mathrm{LL}_{\mathrm{BFR}} \text { and } \mathrm{HI} \text { had similar } \mathrm{GH} \text { and } \\
\text { cortisol responses. HI had higher } \\
\text { RPE and lactate responses than } \\
\text { LL }_{\mathrm{BFR}} \text {. }\end{array}$ \\
\hline Letieri et al., 2018 [25] & 56 females aged $68.8 \pm 5.09$ years. & $\begin{array}{c}\text { Exercises: squat, leg press, knee } \\
\text { extension, and leg curl. } \\
\text { LL } \\
\text { LFR w/high pressure and } \\
\text { LL }_{\text {BFR }} \text { w/low pressure: } 3-4 \times 15 \\
\text { 20-30\% 1-RM } \\
\text { HI- } 3-4 \times 6-8 \\
70-80 \% 1 \text {-RM } \\
\text { Control: ADL's } \\
\text { 16 weeks, } \times 3 / \text { week } \\
\text { 6-weeks detraining }\end{array}$ & $\begin{array}{c}\text { LLBFR W/high pressure- } \\
185.75 \pm 5.45 \mathrm{mmHg} . \\
\mathrm{LL}_{\mathrm{BFR}} \mathrm{W} / \mathrm{low} \\
\text { pressure- } 105.45 \pm 6.5 \mathrm{mmHg} .\end{array}$ & $\begin{array}{l}\mathrm{LL}_{\mathrm{BFR}} \mathrm{w} / \text { both high and low } \\
\text { pressures showed similar increases } \\
\text { in strength as the HI group. }\end{array}$ \\
\hline Manimmanakorn et al., 2013 [26] & $\begin{array}{l}30 \text { female netball athletes, mean } \\
\text { age } 20.2 \pm 3.3 \text { years. }\end{array}$ & $\begin{array}{l}5 \text { weeks of LLRE ( } 20 \% \text { 1RM) for } \\
\text { knee flexor and extensor muscles } \\
\text { with: (1) BFR occlusion around the } \\
\text { upper thighs, ( } 2 \text { normobaric } \\
\text { hypoxic gas, or }(3) \text { no additional } \\
\text { stimulus. Freq.: } 3 \mathrm{~d} \cdot \mathrm{wk}^{-1} \text { of } 3 \text { sets } \\
\text { of knee extensions to failure, } \\
\text { followed by } 3 \text { sets of knee flexions } \\
\text { to failure, with } 30 \mathrm{~s} \text { rest between } \\
\text { sets and } 2 \text { min rest } \\
\text { between exercises. }\end{array}$ & $\sim 230 \mathrm{mmHg}$. & $\begin{array}{l}\text { The exercise protocol with either } \\
\text { BFR or hypoxia increased } \\
\text { muscular strength, endurance, and } \\
\text { CSA compared to control training. } \\
\text { BFR also improved sport-specific } \\
\text { fitness test outcomes over hypoxic } \\
\text { and control training. }\end{array}$ \\
\hline Neto et al., 2017 [18] & $\begin{array}{l}30 \text { untrained females aged } \\
21.7 \pm 3.4 \text { years. }\end{array}$ & $\begin{array}{c}\text { Exercises: biceps curl and knee } \\
\text { extension. } \\
\text { LL: } 1 \times 30,3 \times 15 \\
20 \% 1-\text { RM } \\
\text { LL } \\
\text { BFR: } 1 \times 30,3 \times 15 \\
20 \% 1-R M \\
\text { HL: } 4 \times 8 \\
80 \% 1-R M \\
26 \text { days }\end{array}$ & $\begin{array}{l}80 \% \text { of total arterial } \\
\text { occlusion pressure. }\end{array}$ & $\begin{array}{l}\text { All groups increased SBP, } \mathrm{HR} \text { and } \\
\text { DP but did not increase } \mathrm{SpO}_{2} \text {. } \\
\text { Greatest increase in } \mathrm{HR} \text { and DP in } \\
\text { the luteal phase. }\end{array}$ \\
\hline Rawska et al., 2019 [27] & $\begin{array}{l}4 \text { experienced female } \mathrm{RT} \text { athletes, } \\
\text { mean age } 27.3 \pm 2.2 \text { years. }\end{array}$ & $\begin{array}{c}\text { Four sessions of: } 5 \text { sets of AMRAP } \\
\text { bench press at } 80 \% 1 \text { RM to a fast } \\
\text { or slow tempo with } 3 \text { min rest } \\
\text { between sets. }\end{array}$ & $\sim 80 \%$ full arterial occlusion. & $\begin{array}{l}\text { Both BFR and tempo produced } \\
\text { significant effects on maximum } \\
\text { reps per set. Fast tempo with BFR } \\
\text { resulted in more reps than fast } \\
\text { tempo without BFR, as well as } \\
\text { slow tempo with BFR } \\
\text { versus without. }\end{array}$ \\
\hline Scott et al., 2018 [19] & 15 females aged $63-75$ years. & $\begin{array}{c}\text { Exercises: Leg press and leg } \\
\text { extension. } \\
\text { LL: } 1 \times 20,2 \times 1520 \% 1-\mathrm{RM} \\
\text { LL } 20.15 \mathrm{BFR}: 1 \times 20,2 \times 1520 \% 1-\mathrm{RM} \\
\text { HL: } 3 \times 10,70 \% 1-\mathrm{RM} \\
3 \text { sessions }\end{array}$ & $50 \%$ arterial occlusion pressure. & $\begin{array}{l}\text { LL }_{\text {BFR }} \text { greater SBP, DBP and MAP } \\
\text { than HL. LLBFR and HL have } \\
\text { similar HR responses and } \\
\text { myocardial workload. Soreness } \\
\text { levels were similar in all groups. }\end{array}$ \\
\hline Yasuda et al., 2015 [28] & $\begin{array}{l}14 \text { Japanese females aged } \\
61-85 \text { years. }\end{array}$ & $\begin{array}{l}\text { Exercises: arm curl, triceps press } \\
\text { down with thin yellow band. } \\
\text { LL LFR \& LL group }_{\text {1 } \times 30,3 \times 15} \\
\text { Duration: } 12 \text { weeks, } \times 2 / \text { week. } \\
\text { 12-week detraining. }\end{array}$ & $\begin{array}{l}\text { Started at } 120 \mathrm{mmHg} \text { and } \\
\text { progressed to a max of } 270 \mathrm{mmHg} \text {. }\end{array}$ & $\begin{array}{l}\text { Magnitude of change of muscle } \\
\text { CSA between pre- and } \\
\text { post-exercise was always larger in } \\
\text { the LL LFR group. Twelve-week } \\
\text { detraining reduced muscular } \\
\text { strength and size, but they } \\
\text { remained higher than } \\
\text { pre-training levels. }\end{array}$ \\
\hline
\end{tabular}

Note. ADL: activities of daily living; AMRAP: as many repetitions as possible; BFR: blood flow restriction; CSA cross-sectional area; DBP: diastolic blood pressure; DP: double product; Freq.: frequency; HI: high intensity; HL:

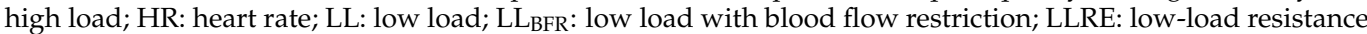
exercise; MAP: mean arterial pressure; MC: menstrual cycle; mmHg: millimeter of mercury; MVC: maximal voluntary contraction; RT: resistance training; $\mathrm{SBP}$ : systolic blood pressure; $\mathrm{SpO}_{2}$ : oxygen saturation; w/: with; w/o: without; 1-RM: 1-repetition maximum. 
The existing scientific literature examining BFR typically utilizes an exercise protocol of low-load RT with BFR, with intensities as low as $20 \%$ one-repetition maximum (1-RM) over 4-8 weeks [29]. However, some studies have examined BFR using aerobic training protocols. A 4-week randomized control trial (RCT) among healthy collegiate females used four different aerobic training protocols: (1) increasing pressure with increasing exercise, (2) increasing pressure with constant exercise, (3) constant pressure with constant exercise, and (4) constant pressure with increasing exercise. In all four groups, $\mathrm{VO}_{2 \max }$ and time to fatigue significantly improved. However, running economy decreased in all groups except for the increasing pressure and increasing exercise group. Results suggest that using aerobic training with BFR may lead to positive physiological changes in $\mathrm{VO}_{2 \max }$ and lengthen one's exercise duration at the expense of running economy [22].

Other studies have examined BFR in RT utilizing higher 1-RM loads. Interestingly, Rawska et al. found that, when comparing total number of bench press repetitions (reps) performed at $80 \%$ 1-RM over five sets with $\sim 80 \%$ full arterial occlusion of the upper arms, female RT athletes performed significantly more reps at a fast tempo (i.e., 2 s eccentric phase) with BFR (38.6 \pm 4.0 reps) than without BFR (29.0 \pm 1.7 reps) [27]. Similar results were also observed at a slow tempo (i.e., 6 s eccentric phase) with BFR (23.6 \pm 0.5 reps) versus without BFR (19.3 \pm 1.5 reps) [27]. Authors report that, while the use of BFR can improve the effectiveness of RT through augmented physiological and metabolic responses, the mechanical work generated by the strain of BFR cuffs can also affect one's exercise capacity during BFR. Future studies should examine these mechanical effects when working with different means of blood flow restriction.

The safety of BFR is often discussed in terms of physiological changes associated with its use. The physiological changes that occur with the use of BFR, such as increased heart rate, blood pressure, and double product, support the recommendation that those using BFR should consult a medical professional prior to its use. A review of the literature surrounding BFR and many different safety concerns, such as venous thromboembolism, presence of reactive oxygen species, and muscle damage, highlights the need for future research to explore this area but also its safe use under the guidance of a medical professional [30]. BFR has been shown to be safe among healthy individuals. While further examination of these physiological changes among female athletes is necessary in the literature, it is also recommended that changes to athletes' biomechanics be examined. A change in running economy while using BFR for aerobic exercise may predispose the female athlete to a risk of injury that otherwise may not be present without using BFR. Future studies should aim to utilize aerobic exercise with BFR and explore changes in running economy and gait with its use in order to provide more data and conclusions on the safety of BFR among female athletes.

Assessing an athlete's soreness can also contribute to recovery. For instance, soreness levels after BFR exercise are similar to those after high-load training without the use of BFR [19]. In comparing low-intensity BFR training to high-intensity training among collegiate females, both subjective and objective assessments of soreness, such as rating soreness levels using a visual analog scale and blood lactate levels, were lower for participants using BFR $[19,20]$. RPE and lactate responses were significantly lower in the BFR group compared to the high-intensity training group as well, suggesting that the use of BFR among females will produce lesser or equal responses in soreness [20].

BFR can also benefit older adults through use of lower training load to achieve similar benefits as those provided by higher load training without the use of BFR. The use of BFR among healthy and active females, especially athletes, is quite limited. Thus, drawing results from an older population of females and applying it to younger and more active populations may not yield similar results. Nevertheless, a small sample of active females over a 4-week training program using BFR with low-load RT showed an increase in maximal voluntary contraction. Furthermore, training at loads as low as $25 \%$ of an individual's 1-RM using BFR provides ample stimulus to improve plantar flexion 1-RM [31]. When combining BFR with whole body vibration training, vastus lateralis cross-sectional area 
(CSA) improved approximately $0.9 \mathrm{~cm}^{2}$ compared to a control group using only whole body vibration training, which improved $0.3 \mathrm{~cm}^{2}$, in a 10-week intervention [24]. Manimmanakorn et al. observed similar results, with CSA of the quadriceps and hamstrings increasing by $6.6 \pm 4.5 \%$ in female netball athletes after a 5-week training period consisting of low-load RT (20\% 1-RM) with KAATSU cuffs around the upper thighs [26]. Interestingly, BFR has not been shown to significantly increase flexibility through its use among females [23]. Therefore, low-load RT when combined with BFR can lead to greater muscle hypertrophy when compared to low loads without BFR. Furthermore, BFR with low-load RT shows similar results in hypertrophy improvements to those of high-load RT without the use of BFR.

While BFR training may be beneficial for certain populations at certain times, it is unlikely in S\&C settings that BFR may be used in every training session, as different mesocycles may have different training and performance emphases with periods of detraining in between. Therefore, it is necessary to understand how a period of detraining might affect the female athlete after BFR training. In a 12-week detraining period following a 12-week training period, a loss of muscle size (i.e., muscle atrophy) and a decrease in muscular strength were found. However, the decreases in muscle size and strength were greater than pre-training measurements [28]. Weekly declines in muscular strength were also found in an RCT implementing a 6-week detraining period following a 16-week training period. The study supports the conclusion that, despite the decrease in muscular strength, the effects of BFR training on muscular strength are still greater than pre-training levels [25]. While decreases to muscle size and strength are expected after a period of detraining, these decreases are generally less severe following BFR. Future studies should aim to include a period of detraining following their training interventions to further understand the relationship between BFR and the effects of detraining.

Although BFR training has been around for many years, it remains an emerging trend. Despite its use, few studies exist that examine the impact of BFR in female athletes. Therefore, providing reasonable recommendations for the use of BFR among female athletes is difficult considering study populations typically use older or younger females who are only recreationally active. $S \& C$ is unique compared to other areas of fitness because its focus is on developing athletic performance. Future research should focus on the effects of BFR within $S \& C$ for females in order to address the literature gap regarding BFR and athletic performance among this population. Of the available scientific literature, BFR training has shown benefits for its use among females. The implementation of BFR into S\&C programs may be limited due to the dearth of literature on its use, budget constraints, potential injury risks, and other factors. Therefore, $\mathrm{S} \& \mathrm{C}$ coaches may find the use of BFR beneficial when used in collaboration with sports medicine departments. By collaborating with sports medicine professionals, $\mathrm{S} \& \mathrm{C}$ coaches may be able to implement BFR training to aid in return to play for injured athletes who may have muscle atrophy, loss of strength, or decreased aerobic capacity of muscles.

\section{Assessment, Screening, and Functional Training}

Researchers and practitioners have sought to solidify functional movement practices by creating both screens and assessments. Screening allows practitioners to sample movement and determine if that movement is either limited and/or asymmetric, whereas an assessment further evaluates movement limitations or asymmetries using diagnostic criteria [32]. Screening and assessment are both purposeful and systematic in their approaches. Movement screening can be defined as a purposeful and systematic approach to identifying deficiencies in mobility and stability among asymptomatic individuals [32]. Providing a baseline of movement competency allows practitioners to form a foundation to design programs around. This is a necessary step in program design as it may help to decrease injuries caused by poor movement competency.

Several types of movement screens are currently being used among S\&C coaches. In order to synthesize the literature on movement screens and assessments, this review 
will focus on the Functional Movement Screen (FMS), the Landing Error Scoring System (LESS), and the Y-Balance Test (YBT). Table 3 provides a summary of selected studies published between 2011 and 2021. The wide availability of different movement screening tools, such as the FMS, LESS, and YBT, aids in their implementation among S\&C coaches. However, a limitation to the wide variety of options in movement screens is determining what movement screen is best.

Table 3. Summary of functional assessments and screening studies among female athletes (2011-2021).

\begin{tabular}{|c|c|c|c|}
\hline $\begin{array}{c}\text { Study } \\
\text { [Reference] }\end{array}$ & Participants & $\begin{array}{c}\text { Assessment/Screening } \\
\text { Tools Used }\end{array}$ & Conclusion \\
\hline Benis et al., 2016 [33] & $\begin{array}{l}28 \text { elite female Italian national } \\
\text { league basketball players aged } \\
\qquad 20 \pm 2 \text { years. }\end{array}$ & YBT & $\begin{array}{l}\text { Eight-week neuromuscular training program } \\
\text { (body weight core stability and plyometric } \\
\text { exercises) improved composite YBT scores for } \\
\text { both lower limbs from baseline in EXP group as } \\
\text { compared to CON group. Improvements in } \\
\text { posterolateral and posteromedial directions were } \\
\text { seen in EXP group, but not in anterior reach. }\end{array}$ \\
\hline Brumitt et al., 2018 [34] & $\begin{array}{l}106 \text { NCAA DIII female soccer, } \\
\text { volleyball, XC, basketball, lacrosse, } \\
\text { tennis, softball, and track athletes, } \\
\text { mean age } 19.1 \pm 1.1 \text { years. }\end{array}$ & $\begin{array}{l}\text { SLJ } \\
\text { SLH } \\
\text { LEFT }\end{array}$ & $\begin{array}{l}\text { Suboptimal scores on each test were associated } \\
\text { with significantly increased risk for initial and } \\
\text { total time-loss LQ injury, particularly at the thigh } \\
\text { or knee. At-risk athletes with a history of LQ } \\
\text { sports injuries and less active off-season training } \\
\text { habits had an 18-fold increased risk of a } \\
\text { time-loss thigh or knee injury during the season. }\end{array}$ \\
\hline Clay et al., 2016 [35] & $\begin{array}{l}37 \text { NCAA DI Collegiate female } \\
\text { rowers, mean age } 19.4 \pm 1.2 \text { years. }\end{array}$ & FMS & $\begin{array}{l}\text { Previous history of LBP resulted in being } 6 \text { times } \\
\text { more likely to experience LBP during the season. } \\
\text { Greater rowing experience (years) was } \\
\text { associated with higher reports of LBP. FMS was } \\
\text { not statistically significant in predicting time loss } \\
\text { injury in female collegiate rowers. }\end{array}$ \\
\hline Dorrel et al., 2018 [36] & $\begin{array}{l}257 \text { NCAA DII female }(n=81) \text { and } \\
\text { male }(n=176) \text { collegiate athletes, } \\
\text { ages between } 18 \text { and } 24 \text { years. }\end{array}$ & FMS & $\begin{array}{c}\text { A cutoff score of } \leq 15 \text { was associated with } \\
\text { relative risk of } 1.25,1.25 \text {, and } 1.45 \text { for } \\
\text { musculoskeletal, overall, and severe injuries in } \\
\text { this sample, respectively. Due to AUC scores of } \\
\text { 0.54, } 0.56 \text {, and } 0.53 \text { for musculoskeletal, overall, } \\
\text { and severe injuries, respectively, authors regard } \\
\text { the FMS as slightly better than chance at } \\
\text { predicting injuries among this group. }\end{array}$ \\
\hline Landis et al., 2018 [37] & $\begin{array}{c}187 \text { female NAIA varsity-level } \\
\text { soccer, basketball, and volleyball } \\
\text { players, mean age } 19.5 \pm 1.21 \text { years. }\end{array}$ & $\begin{array}{c}\text { FMS } \\
\text { Drop-jump landing }\end{array}$ & $\begin{array}{c}\text { Non-contact LE injured participants }(n=17) \\
\text { scored significantly lower on the FMS }(14 \pm 3.46 \\
\text { and } 15.35 \pm 2.58) \text {. Previous ACL injury } \\
\text { demonstrated lower FMS scores }(13.84 \pm 3.611) \\
\text { compared to non-injured participants } \\
(15.30 \pm 2.732) \text { and significantly predicted future } \\
\text { LE injury. Poorer drop-jump landing mechanics } \\
\text { were not significantly associated with injury, } \\
\text { though trends existed. }\end{array}$ \\
\hline Ness et al., 2016 [38] & $\begin{array}{l}17 \text { NCAA DI female soccer athletes, } \\
\text { mean age } 18.8 \pm 0.9 \text { years. }\end{array}$ & $\begin{array}{l}\text { SEBT } \\
\text { Isometric hip strength }\end{array}$ & $\begin{array}{l}\text { Following } 8 \text { weeks of offseason training, SEBT } \\
\text { composite reach distance improved in both } \\
\text { dominant and non-dominant limbs. Dominant } \\
\text { hip external rotation strength gains also appear } \\
\text { to be associated with improved lower extremity } \\
\text { dynamic balance. }\end{array}$ \\
\hline Šiupšinskas et al., 2019 [39] & $\begin{array}{l}169 \text { professional female basketball } \\
\text { players of the XWBL league, mean } \\
\text { age } 23.1 \pm 5.7 \text { years. }\end{array}$ & $\begin{array}{l}\text { YBT-LQ } \\
\text { FMS } \\
\text { LESS }\end{array}$ & $\begin{array}{l}\text { Injured players }(n=92) \text { scored } 1.3 \text { points lower } \\
\text { on the FMS }(14.1) \text { than non-injured }(n=77) \\
\text { players }(15.4) \text { and } 1 \text { point higher on the LESS }(8) \\
\text { than non-injured players }(7) \text {. Group differences } \\
\text { for YBT-LQ scores were not } \\
\text { statistically significant. }\end{array}$ \\
\hline Sprague et al., 2014 [40] & $\begin{array}{l}57 \text { NCAA DII female }(n=37) \text { and } \\
\text { male }(n=20) \text { volleyball and soccer } \\
\text { athletes, mean age } 19.7 \pm 1.3 \text { years. }\end{array}$ & FMS & $\begin{array}{l}\text { FMS composite scores did not differ between pre- } \\
\text { and post-season, although all teams trended } \\
\text { toward improvements. All teams reduced total } \\
\text { number of asymmetries between measurements } \\
\text { as well. In terms of individual movements, all } \\
\text { athletes improved on the deep squat and in-line } \\
\text { lunge, while worsening on the active straight leg } \\
\text { raise and rotary stability movement. }\end{array}$ \\
\hline
\end{tabular}


Table 3. Cont.

\begin{tabular}{|c|c|c|c|}
\hline $\begin{array}{c}\text { Study } \\
\text { [Reference] }\end{array}$ & Participants & $\begin{array}{l}\text { Assessment/Screening Tools } \\
\text { Used }\end{array}$ & Conclusion \\
\hline Stapleton et al., 2021 [41] & $\begin{array}{l}38 \text { NCAA DI male }(n=23) \text { baseball } \\
\text { and female }(n=15) \text { softball athletes, } \\
\text { mean age } 20.0 \pm 1.38 \text { years. }\end{array}$ & $\begin{array}{c}\text { FMS } \\
\text { YBT-UQ } \\
\text { YBT-LQ } \\
\text { Athletic performance (vertical } \\
\text { jump, pro-agility, rotational } \\
\text { medicine ball throw) }\end{array}$ & $\begin{array}{l}\text { In female softball athletes, significant negative } \\
\text { correlations were found between composite FMS } \\
\text { and RMTR; between RMTR and FMS in-line } \\
\text { lunge, YBT-LQ anterior reach, and YBT-LQ } \\
\text { posterolateral reach; and between pro-agility and } \\
\text { YBT-LQ posterolateral reach and YBT-UQ } \\
\text { superolateral reach. Vertical jump was } \\
\text { significantly positively correlated with YBT-LQ } \\
\text { posterolateral reach and YBT-UQ superolateral } \\
\text { reach. Overall, composite scores of FMS, } \\
\text { YBT-LQ, and YBT-UQ did not significantly } \\
\text { predict total performance. Individual } \\
\text { components (active straight leg raise and hurdle } \\
\text { step) significantly predicted total performance. }\end{array}$ \\
\hline Walbright et al., 2017 [42] & $\begin{array}{l}35 \text { NCAA DI collegiate female } \\
\text { basketball }(n=17) \text { and volleyball } \\
\qquad(n=18) \text { players. }\end{array}$ & $\begin{array}{l}\text { YBT } \\
\text { FMS } \\
\text { SLH }\end{array}$ & $\begin{array}{c}\text { FMS, YBT, and SLHT did not show a relationship } \\
\text { between composite score and lost time LQ injury. } \\
\text { The tests were not predictive of LQ } \\
\text { injury occurrence. }\end{array}$ \\
\hline Warren et al., 2015 [43] & $\begin{array}{l}167 \text { NCAA DI female }(n=78) \text { and } \\
\text { male }(n=89) \text { collegiate athletes, } \\
\text { mean age } 20.3 \pm 1.5 \text { years. }\end{array}$ & FMS & $\begin{array}{l}\text { No association between FMS composite score } \\
\text { and non-contact injury was found within this } \\
\text { sample. Authors also found no association } \\
\text { between FMS movement pattern asymmetry and } \\
\text { injury. In comparison to other studies, the FMS } \\
\text { might be better suited at predicting injury in } \\
\text { contact or traumatic injuries. }\end{array}$ \\
\hline Warren et al., 2020 [44] & $\begin{array}{l}68 \text { NCAA DI female basketball, } \\
\text { soccer, and volleyball athletes, } \\
\text { mean age } 19.1 \pm 1.1 \text { years. }\end{array}$ & $\begin{array}{c}\text { SLH } \\
\text { THT } \\
\text { XCT } \\
\text { Isometric hip strength }\end{array}$ & $\begin{array}{l}\text { THT score significantly predicted non-contact } \\
\text { injury risk in this group. Athletes in the weakest } \\
\text { tertile for hip external rotation strength were at } \\
\text { increased odds of injury compared to the } \\
\text { strongest tertile as well. }\end{array}$ \\
\hline Zibaie et al., 2019 [45] & $\begin{array}{l}58 \text { Iranian female athletes, mean } \\
\text { age } 21.11 \pm 7.71 \text { years. }\end{array}$ & $\begin{array}{l}\text { FMS } \\
\text { Core proprioception } \\
\text { (using gyroscope) } \\
\text { Anthropometric data }\end{array}$ & $\begin{array}{l}\text { Correlations between FMS composite scores and } \\
\text { core proprioception and anthropometric } \\
\text { dimensions were not statistically significant. }\end{array}$ \\
\hline
\end{tabular}

Note. AAA: Athletic Ability Assessment; ACL: anterior cruciate ligament; AUC: area under the curve; CON: control; DI: division one; DII: division two; DIII: division three; EXP: experimental; FMS: Functional Movement Screen; FPT: Functional Performance Test; LBP: low back pain; LE: lower extremity; LEFT: Lower Extremity Functional Test; LESS: Landing Error Scoring System; LQ: lower quarter; NAIA: National Association of Intercollegiate Athletics; NCAA: National Collegiate Athletic Association; RMTR: rotational medicine ball thrown to the right; SEBT: Star Excursion Balance Test; SLH: Single Leg Hop for Distance Test; SLJ: Standing Long Jump Test; THT: Triple Hop Test for Distance; XHT: Crossover Hop Test for Distance; XWBL: X Women's Basketball League; XC: cross-country; YBT: Y-Balance Test; YBT-LQ: Y-Balance Test, Lower Quarter Screen; YBT-UQ: Y-Balance Test, Upper Quarter Screen.

The increase in participation in sports among collegiate female athletes is also coupled with an increased rate of injuries. For example, injuries to the lower extremity account for approximately $59 \%$ of all injuries for female NCAA basketball athletes [46]. Among those, anterior cruciate ligament (ACL) injuries are one of the most common and widely studied injuries among female athletes. Additionally, female collegiate athletes experience an increased incidence of sport-related injuries when compared to their male counterparts [34]. The high rate of lower body injury among female athletes has led to a surge in both research and clinical practice to prevent injury. Particular care should be taken by researchers and practitioners to identify and remain cognizant of the effects and interactions of the MC on non-contact injury risk in female athletes as well.

Among current trends in injury prevention is the use of movement screening. The purpose of a movement screen is to identify at-risk individuals, assist in program design through the use of corrective exercises to improve fundamental movement patterns, track development or improvement of movement patterns, and create a baseline measurement of fundamental movement with objective measurements [47]. By using a movement screen, S\&C coaches can identify dysfunctional movement patterns and/or movement patterns that have not been developed properly. Dysfunctional movement patterns are inefficient and may be hiding movement compensations. Identifying movement dysfunctions allows the $\mathrm{S} \& \mathrm{C}$ coach to implement strategies to correct the dysfunction. Furthermore, correcting 
the movement dysfunction may lead to more efficient movements, which in turn may influence a positive change in biomechanics and ultimately help to reduce one's risk of injury [44]. A common misconception of movement screening and assessments is its ability to predict athletic performance. Those who have scored higher in flexibility measures have been shown to score higher on the FMS, yet higher scores on the FMS or YBT were not significantly correlated with improved athletic performance $[40,41,48]$.

\subsection{The Functional Movement Screen}

Among the available movement screens, three have been frequently used in the literature among female athletic populations: the FMS, the YBT, and the LESS. Among these three, the FMS is the most widely adopted screening tool for both researchers and clinicians. The FMS is composed of seven foundational movements (i.e., deep squat, hurdle step, inline lunge, shoulder mobility, active straight leg raise, trunk stability push-up, and rotary stability) pertaining to a range of mobility and stability competencies [43]. Each movement is performed barefoot over three trials, where the best rep is recorded and graded on a scale from zero to three, where a " 0 " indicates pain with the movement and " 3 " indicates proper form of the movement [35]. Therefore, the maximum composite score on the FMS is 21 points [49]. A composite score allows for a snapshot view of FMS overall; viewing only the composite score, however, does not allow the S\&C coach to evaluate individual movement patterns that contributed to the overall score. Therefore, S\&C coaches should aim to examine the scores of each movement pattern within the screen that contributed to the composite score. It has been suggested in the literature that a score of 14 or less is significantly correlated with risk of injury $[40,50]$. However, conflicting evidence exists in the literature as a score of 14 or more on the FMS has also been associated with an increased risk of injury. Therefore, the total score of the FMS should not be used as a sole predictor of injury $[39,43]$. A zero score on a movement in the FMS, indicating that the subject had pain with the given movement, may have implications as an early warning sign of injury [51]. Regardless, caution should be used when using a zero score on the FMS as a warning sign of injury, as data have also shown that pain during the FMS was not a predictor of injury [37].

The validity of the FMS as a predictor of injury also has varying results in the literature. Many studies appear to show that injury rates are higher among those who scored lower in the FMS when compared to those who did not sustain an injury during their sporting season $[35,42]$. Yet, many studies fail to reach statistical significance showing that a lower FMS score is associated with increased risk of future injury [34], while others state that the FMS is slightly better than 50/50 chance at accurately classifying those at increased risk for injury [36]. Analysis of the FMS pertaining to specific sports has also produced interesting results in the literature. Female combat sport athletes have scored higher, although not statistically significantly higher than football and basketball athletes [39]. Among female collegiate DI rowing athletes, the FMS was not a significant predictor of injury, and authors suggest that the FMS was not sport-specific enough to rowing (i.e., rowing utilizes multiplane spinal movements from a seated position, whereas the FMS does not) [35]. Rather than rely on composite scores, researchers instead suggest that individual component scores should be considered and used to implement athlete- and sport-specific strength and mobility programs to better correct movement dysfunctions, affect athletic performance, and reduce future injury risk [41].

The FMS also does not include a history section in its screening and thus does not record previous history of injury to a body part or region. Therefore, studies analyzing the FMS and injury prediction often do not include history of previous injury. Previous history of knee injury, or more generally, previous history of lower extremity injuries, has been reported as a risk factor for future injury to the area $[38,52,53]$. Female collegiate DI rowing athletes with a history of low back pain were six times more likely to suffer from low back pain during season compared to those who did not report a previous history of low back 
pain [35]. Therefore, $S \& C$ coaches should be aware of previous history of injury as it may show predictive signs of future injury.

Choosing to use any type of screen or assessment should come with a plan. Use of the data obtained from the screening or assessment and how that data might be implemented in S\&C programs should be considered before implementing a movement screen or assessment. Female athletes will not benefit from the mere collection of movement data without the use of corrective exercises to combat individual movement dysfunctions. Among high school female student-athletes, researchers have found deficits in core strength. However, in a short prescribed corrective exercise program of 4 weeks, high school female studentathletes have shown improvements in their core strength [54]. Therefore, thoughtful use and application of a movement screen or assessment in programming for the female athlete may aid in addressing and correcting movement dysfunctions.

ACL injury is widely discussed among sports medicine and $S \& C$ coaches for female athletes. Female soccer athletes and female basketball athletes have been shown to have roughly a three times greater risk of ACL injury compared to male athletes [55]. This presents a concern for both sports medicine professionals and S\&C coaches to address in the female athlete. A study among professional female basketball athletes in the pre-season found that the most common injuries during the season were knee related, accounting for a total of $40.2 \%$ of injuries. These included injuries to the ACL, medial collateral ligament (MCL), and lateral collateral ligaments (LCL). FMS displayed no significant difference in predicting injury between injured and non-injured professional female basketball athletes [39] or NCAA DI student-athletes [43]. However, injured professional female basketball players scored on average 1.3 times higher on the FMS compared to their noninjured counterparts [39]. Therefore, not looking solely at the composite score of the FMS and the addition of multiple screening tools may better help predict injury risk among female athletes.

\subsection{The Landing Error Scoring System}

Various other methods of gathering objective data on movement exist for female athletes, such as the LESS and YBT. Jumping mechanics are thought to play a role in noncontact ACL injuries, especially among females. Female athletes with a history of an ACL tear show an altered knee posture and loading compared to those who have not sustained a previous ACL injury. A previous history of ACL tear for female athletes is also associated with an increase in knee valgus upon landing [56]. The LESS is a validated and reliable tool for the assessment of landing mechanics after a jump [57]. The LESS is set up based on an athlete's height; the athlete will jump forward from a $30 \mathrm{~cm}$ box towards the ground to an equivalent distance of half their height, then immediately perform a vertical jump upon landing. Viewing the athletes' landing from the sagittal and frontal planes will allow the practitioner to examine the athletes' landing characteristics in multiple planes to determine differences in movements such as angles of flexion/extension and abduction/adduction. Fatigue also plays an important factor in landing mechanics. For example, female athletes scored higher on the LESS after a period of intense lower body training [58]. The increase in knee valgus upon landing may be correlated to a lack of neuromuscular control of the knee [56], and future research should explore ACL injury prevention programming for female athletes focusing on neuromuscular control of the knee upon landing to avoid valgus collapse of the knee.

\subsection{The Y-Balance Test}

The YBT is a reliable method to objectively analyze dynamic balance [59]. Assessing dynamic balance using the YBT allows the practitioner to examine core and extremity function by quartering the body and placing it under body weight loads [60]. The YBT has both an upper quarter (YBT-UQ) and a lower quarter screen (YBT-LQ); for the purpose of this section, literature regarding the YBT-LQ will be emphasized. The YBT-LQ is similar to that of the Star Excursion Balance Test (SEBT) in that it tests single leg balance in multiple 
directions. However, it differs primarily in the number of directions tested. The three movements composed in the YBT-LQ are a single stance with contralateral limb reach in the anterior, posterior-medial, and posterior-lateral directions. Composite scores of the YBT-LQ and a modified version of the SEBT (so that the YBT tests the same three reaches) in healthy adolescent females did not differ, but scores did differ in the anterior reach direction [61]. Additionally, a small sample of 25 females who suffered an ACL injury demonstrated that there were no significant differences in the anterior reach direction when compared to non-ACL injured females [62]. Moreover, professional female basketball players improved their YBT-LQ composite, posterior-medial, and posterior-lateral scores after an 8-week intervention of neuromuscular training of bodyweight core and plyometric exercises. Therefore, S\&C coaches may find it valuable to incorporate neuromuscular training into their warm-ups to aid in injury prevention by increasing joint awareness and postural control [33].

Performance measurements are common among S\&C coaches to evaluate and track athletic-performance-based outcomes. Performance measurements have also been studied in the literature as a predictor of injury, such as a $10 \mathrm{~m}$ sprint, single leg three hop test, and $2 \mathrm{k}$ timed run. Within tactical populations, literature has shown that performancebased measurements have both higher sensitivity and specificity when compared to total FMS scores as a predictor of injury [51]. Performance-based measurements are often used at various points throughout the year for athletes. Performance measurements represent a cheap and easily implemented measurement tool for $S \& C$ coaches to use. Other examples of performance measures used by S\&C coaches include the standing long jump, vertical jump, and pro-agility test. The pro-agility test significantly correlates with FMS composite scores in male high school athletes and YBT score in female high school athletes [63]. Currently, these measurement tools are primarily used to assess and track athletic performance. Limitations of the FMS include financial cost, requirement of a trained provider to implement it, and time associated with testing a respective group such as an entire sports team. Therefore, performance measurements such as $10 \mathrm{~m}$ sprint time, single leg three hop distance, $2 \mathrm{k}$ run time, standing long jump, vertical jump, or the pro-agility test may provide a more effective predictor of injury. Future trends should aim to explore this relationship further. In addition, anthropometric measurements have been shown to have a more significant relationship with motor functions than the FMS [45].

In conclusion, a broad range of assessments and screenings such as the FMS, LESS, and YBT add to our understanding for better programming for sports performance. Injuries in athletics are often multifactorial and require holistic examination. Movement screening is just one piece of this holistic structure that can aid in the prediction and prevention of injury. Conflicting evidence exists for the relationship of injury in females in the FMS and YBT $[39,62,63]$. Therefore, S\&C coaches should not rely solely on one movement screen. S\&C coaches should utilize multiple methods to evaluate functional movement [63]. Future research on functional screening should aim to further analyze various different functional screening and assessment methods in their relationship with injury prevention. Scientific literature surrounding currently available movement screening and assessment tools should aim to incorporate females and more specifically female athletes as well.

\section{Technology in Sports}

As technology continues to advance, so does inclusion of technology in S\&C. Generally, the increased use of technology in sports often incorporates various aspects of performance tracking, recovery tracking, and integration of data into larger programming strategies. Most of these measurements deal with internal physiological responses to training (e.g., HRV, oxygen saturation, response times, etc.) as well as larger sport-related movements during practice or competition (e.g., change of direction, acceleration or deceleration, quantifying training and player load, etc.). Researchers should understand how technology is being integrated into larger S\&C practices in order to remain abreast of current and emerging trends. The inclusion of technology into S\&C can provide numerous objective 
data points with which coaches and researchers can design, monitor, and assess training programs to better promote physiological adaptations, reduce injury risk, and advance return-to-play protocols following rehabilitation $[64,65]$. However, the inclusion of females and more specifically female athletes is severely underrepresented in the literature.

Table 4 provides a summary of the selected studies published between 2011 and 2021 .

Table 4. Summary of technology in sports studies among female athletes (2011-2021).

\begin{tabular}{|c|c|c|c|}
\hline $\begin{array}{c}\text { Study } \\
\text { [Reference] }\end{array}$ & Participants & Measurement/Technology & Conclusion \\
\hline Barrero et al., 2019 [66] & $\begin{array}{l}10 \text { European regional- or } \\
\text { national-level female cyclists, mean } \\
\text { age } 31.7 \pm 4.7 \text { years. }\end{array}$ & HRV (1000 Hz HR monitor) & $\begin{array}{c}\text { Higher daily workload from intense } \\
\text { exercise correlated to higher supine HR } \\
\text { after a recovery night. One-week rest from } \\
\text { intense exercise was enough to restore } \\
\text { baseline HRV values after } 21 \text { days of Tour } \\
\text { de France stages. }\end{array}$ \\
\hline Benjamin et al., 2020 [67] & $\begin{array}{l}19 \text { NCAA DI female soccer athletes, } \\
\text { mean age } 20.6 \pm 1.4 \text { years. }\end{array}$ & GPS (100 Hz accelerometers) WBGT & $\begin{array}{l}\text { Statistically significant differences in } \\
\text { relative distance, relative high-speed } \\
\text { running distance, and relative high } \\
\text { metabolic load were observed with } \\
\text { increasing WBGT risk categories for } \\
\text { hyperthermia. Individuals differed in } \\
\text { effects of performance associated with } \\
\text { heat acclimation. Decreases in relative } \\
\text { high-speed running distance seemed to } \\
\text { negatively correlate with aerobic fitness } \\
\text { level as well. }\end{array}$ \\
\hline Bozzini et al., 2021 [64] & $\begin{array}{l}20 \text { NCAA DI female beach } \\
\text { volleyball players, mean age } \\
20 \pm 1 \text { years. }\end{array}$ & $\begin{array}{l}\text { Integrated GPS and HR } \\
\text { monitoring technology }\end{array}$ & $\begin{array}{l}\text { Average workloads were higher in } \\
\text { practices than matches, but match } \\
\text { workloads surpassed those of practice } \\
\text { when pre-match warm-ups were factored } \\
\text { in. Athletes expended over } 500 \text { calories on } \\
\text { average during matches as well. }\end{array}$ \\
\hline Costa et al., 2021 [68] & $\begin{array}{l}34 \text { Portuguese high-level outfield } \\
\text { female soccer players, mean age } \\
20.6 \pm 2.3 \text { years. }\end{array}$ & $\begin{array}{c}\text { Sleep quality } \\
\text { HRV (HR monitor and wrist-worn } \\
\text { accelerometer) }\end{array}$ & $\begin{array}{c}\text { Sleep duration ranged between } 6.5 \text { to } 8.8 \mathrm{~h} \\
\text { and decreased after evening training } \\
\text { sessions. Sleep efficiency ranged between } \\
86 \% \text { and } 90 \% \text {. Nocturnal heart rate } \\
\text { variability indices were normal. No } \\
\text { differences in sleep efficiency, nocturnal } \\
\text { HRV, and perceived ratings of wellbeing } \\
\text { were observed over the } 2 \text {-week study } \\
\text { period. Within-match workloads } \\
\text { accounting for two matches play per day } \\
\text { equated to two } 90 \text { min soccer games over } \\
\text { a weekend. }\end{array}$ \\
\hline Flatt et al., 2016 [69] & $\begin{array}{l}12 \text { NAIA collegiate female soccer } \\
\text { players, mean age } 22 \pm 2.3 \text { years. }\end{array}$ & HRV (chest strap Polar transmitter) & $\begin{array}{l}\text { Decrease in vagal HR index (Ln rMSSD) } \\
\text { demonstrated greater improvements on } \\
\text { Yo-Yo Intermittent Recovery Test } \\
\text { following } 5 \text { weeks of offseason training. } \\
\text { HRV data gathered via smartphone } \\
\text { showed meaningful training } \\
\text { status information. }\end{array}$ \\
\hline Flatt et al., 2017 [70] & $\begin{array}{l}8 \text { NCAA DI female soccer players, } \\
\text { mean age } 20.2 \pm 1.8 \text { years. }\end{array}$ & $\begin{array}{c}\text { HRV (pulse-wave finger sensor) } \\
\text { HR monitor (chest strap } \\
\text { Polar transmitter) }\end{array}$ & $\begin{array}{l}\text { Increased training load is correlated with } \\
\text { decreased cardiac parasympathetic } \\
\text { modulation (a measure sensitive to } \\
\text { fatigue). The opposite was found with a } \\
\text { decrease in training load. }\end{array}$ \\
\hline Hoshikawa et al., 2013 [71] & $\begin{array}{l}7 \text { intercollegiate female } \\
\text { middle-distance runners, mean age } \\
19.6 \pm 0.8 \text { years. }\end{array}$ & $\begin{array}{l}\text { Sheet-type nocturnal sleep } \\
\text { monitoring sensor } \\
\text { Normobaric hypoxia room }\end{array}$ & $\begin{array}{l}\text { Increased } \mathrm{HR}, \mathrm{RR} \text {, and restlessness, and } \\
\text { decreased } \mathrm{SpO}_{2} \text { were observed during } \\
\text { hypoxic night } 1 \text {. However, physiological } \\
\text { variables progressed toward normoxic } \\
\text { levels within } 1 \text { week. }\end{array}$ \\
\hline Kupperman et al., 2021 [65] & $\begin{array}{l}32 \text { NCAA DI female collegiate } \\
\text { soccer players, mean age } \\
20 \pm 1 \text { years. }\end{array}$ & GPS (10 and $100 \mathrm{~Hz}$ sampling rate) & $\begin{array}{l}\text { Total distance and player loads were twice } \\
\text { as high during practices than games. } \\
\text { During practice sessions, defenders } \\
\text { displayed the highest median player loads } \\
\text { of all positions during practices, while } \\
\text { midfielders had the highest median player } \\
\text { loads during games. }\end{array}$ \\
\hline
\end{tabular}


Table 4. Cont.

\begin{tabular}{|c|c|c|c|}
\hline $\begin{array}{c}\text { Study } \\
\text { [Reference] }\end{array}$ & Participants & Measurement/Technology & Conclusion \\
\hline McKeown et al., 2016 [72] & $\begin{array}{l}12 \text { Australian national-level female } \\
\text { netball athletes, mean age } \\
19.9 \pm 0.4 \text { years. }\end{array}$ & Linear position transducer (barbell) & $\begin{array}{l}\text { Loaded countermovement jumps } \\
\text { performed resulted in power and jump } \\
\text { height improvements at an earlier time } \\
\text { than the unloaded condition. Frequent } \\
\text { monitoring of performance variables } \\
\text { across different jump types can prove } \\
\text { more informative to coaching practices } \\
\text { than focusing on jump height alone. }\end{array}$ \\
\hline Perrotta et al., 2019 [73] & $\begin{array}{c}24 \text { Canadian national team female } \\
\text { field hockey players, mean age } \\
22.6 \pm 3.0 \text { years }\end{array}$ & $\begin{array}{l}\text { HR monitor (POLAR Team², } \\
1000 \mathrm{~Hz} \text { sampling rate) }\end{array}$ & $\begin{array}{l}\text { Significant correlation between } \\
\text { experienced and prescribed training loads } \\
\text { through a 5-week final preparatory } \\
\text { mesocycle was found. Minimal deviations } \\
(-5.4 \text { to } 7.1 \%) \text { in weekly prescribed } \\
\text { training loads were also observed. } \\
\text { Overall, fitness levels did not significantly } \\
\text { correlate with magnitude of deviation. }\end{array}$ \\
\hline Ransdell et al., 2020 [74] & $\begin{array}{l}6 \text { NCAA DI female basketball } \\
\text { players, mean age } 19.7 \pm 1.5 \text { years. }\end{array}$ & Catapult Optimeye S5 unit & $\begin{array}{l}\text { Athletes' jumps increased over the 4-year } \\
\text { playing period. Player load per minute } \\
\text { was also higher among guard positions } \\
\text { than posts. Athletes experienced increased } \\
\text { high-inertial movement analysis in games } \\
\text { that were lost than were won as well. }\end{array}$ \\
\hline Sekulic et al., 2014 [75] & $\begin{array}{l}57 \text { college-aged female }(n=21) \text { and } \\
\text { male }(n=36) \text { athletes, mean age } \\
21.8 \pm 2.5 \text { years. }\end{array}$ & Computer-managed agility course & $\begin{array}{l}\text { Male athletes of agility-saturated sports } \\
\text { performed better on a reactive agility test } \\
\text { than male athletes of non-agility sports; } \\
\text { this instance was not observed among } \\
\text { female athletes. Reactive and nonreactive } \\
\text { practices were found to share } 36-46 \% \\
\text { common variance. All athletes performed } \\
\text { better during the change of direction drill } \\
\text { than the reactive agility test. }\end{array}$ \\
\hline Strauss et al., 2019 [76] & $\begin{array}{l}30 \text { South African sub-elite female } \\
\text { soccer players, mean age } \\
22.8 \pm 2.4 \text { years. }\end{array}$ & $\begin{array}{c}\text { GPS }(100 \mathrm{~Hz} \text { accelerometers) } \\
\text { HR monitor (fix Polar } \\
\text { transmitter belt) }\end{array}$ & $\begin{array}{l}\text { Positional distinctions in distance traveled } \\
\text { during matches were observed with } \\
\text { midfielders }(84.4 \mathrm{~m} / \mathrm{min}) \text { reporting the } \\
\text { greatest. Defenders spent the greatest time } \\
\text { in the high-intensity HR zone per minute } \\
(13.3 \%) ; \text { forwards spent the least }(9.7 \%) \text {. } \\
\text { Mean HR during matches: } 159 \mathrm{bpm}(81 \% \\
\left.\text { of } \mathrm{HR}_{\max }\right) \text {. All match variables decreased } \\
\text { in the second half. }\end{array}$ \\
\hline Tian et al., 2013 [77] & $\begin{array}{l}34 \text { Chinese national team female } \\
\text { wrestlers, mean age } 23.0 \pm 3.0 \text { years }\end{array}$ & $\begin{array}{l}\text { HRV (OmegaWave sport } \\
\text { technology system, } \\
\text { millisecond sampling) }\end{array}$ & $\begin{array}{c}\text { Large deviations above and below normal } \\
\text { HRV indices (rMSSD and SDNN) lasting } \\
>2 \text { weeks indicated nonfunctional } \\
\text { overreaching in athletes. Associated } \\
\text { changes in HRV indices lasted for } \\
>3 \text { weeks, concurring with decreased } \\
\text { physical performance, in those } \\
\text { experiencing nonfunctional overreaching. }\end{array}$ \\
\hline Vlantes \& Readdy 2017 [78] & $\begin{array}{l}11 \text { NCAA DI female collegiate } \\
\text { volleyball players, aged } \\
18-21.9 \text { years. }\end{array}$ & Catapult Optimeye S5 Microsensors & $\begin{array}{l}\text { Setters displayed the highest mean player } \\
\text { load, as well as the highest number of } \\
\text { jumps of all positions in a 5-1 system. } \\
\text { Individual differences based on position } \\
\text { were observed for changes to player } \\
\text { loading, percentage of high-impact player } \\
\text { load, and jumps over 3-, 4-, or } \\
\text { 5-set matches. }\end{array}$ \\
\hline
\end{tabular}

Note. bpm: beats per minute; DI: division one; GPS: global positioning system; HR: heart rate; $\mathrm{HR}_{\max }$ : $\max$ heart rate; HRV: heart rate variability; Ln rMSSD: logarithm of the root mean square of successive R-R interval differences; km: kilometers; m/min: meters per minute; NAIA: National Association of Intercollegiate Athletics, NCAA: National Collegiate Athletic Association; rMSSD: square root of the mean of the sum of the squares of differences between adjacent R-to-R intervals; RR: respiratory rate; SDNN: standard deviation of all normal R-to-R intervals; $\mathrm{SpO}_{2}$ : oxygen saturation; WBGT: wet-bulb globe temperature; 1-RM: 1-repitition maximum.

\subsection{Velocity-Based Training}

Programming is an integral part in preparing the female athlete for athletic performance. Proper set and repetition schemes with appropriate rest intervals can play a factor in the female athlete's performance. Additionally, training loads should be prescribed based on training goals and training phase. One repetition maximum testing is widely used 
among S\&C professionals to prescribe training loads as a percentage of 1-RM (\%1-RM), or relative load. Movement velocity may offer an additional method of measuring load percentages for programming in female athletes. Weakley and colleagues refer to velocitybased training as "a method that uses velocity to inform or enhance training practice" [79] (p. 31). Load-velocity relationships among females have been proven to be accurate both in stronger and weaker females [80]. This finding provides evidence to support the use of barbell velocity as an alternative measure to assessing 1-RM and using \%1-RM in programming regardless of the strength of the female athlete, as suggested by Torrejón et al. [80]. Interestingly, female athletes have shown higher barbell velocity when performing heavy loads on bench press compared to males. However, females showed lower barbell velocity when performing lighter loads on bench press compared to males [81].

The literature on the use of velocity-based training in $S \& C$ is lacking in female athlete inclusion [82]. It has been found that among males, the use of barbell velocity training can have a positive effect on training. Training at higher maximal velocities leads to greater gains in strength compared to lower velocities [83]. Barbell velocity-based training is becoming popular within S\&C for a variety of reasons, one of which is the feasibility of its application. Products that measure barbell velocity are typically used in research to detect changes in speed. For example, Bozzini and colleagues utilized a TENDO unit attached to a $20 \mathrm{~kg}$ barbell to measure jump velocity among female NCAA DI beach volleyball players [64]. Similarly, McKeown et al. used a linear position transducer attached to either a wooden dowel or $15 \mathrm{~kg}$ barbell to assess peak movement velocity, mean concentric power, and maximum jump height during multiple countermovement jumps among female netball players [72]. Measurements of force, which are important in determining power, can be measured using barbell velocity measurements through change barbell speed, or by using force plates to assess ground reaction forces, contact time, and flight time, and to calculate the reactive strength index $[72,84]$. Linear velocity transducers come in many different styles, including smartphone applications with Bluetooth connectivity, making the consumer market rather versatile for their implementation.

Maintaining velocity throughout the training session in strength-based phases is important as training at higher velocities rather than lower velocities can lead to greater strength gains [83]. The greatest difference in average training velocity using the bench press was observed in the last repetitions of the set [81], suggesting that velocity may decrease as repetitions increase for the bench press. Furthermore, the addition of longer intra-set rest periods may aid in recovery between sets to combat this fatigue, although future research is needed to further support this, especially among females.

\subsection{Wearable Technology-Motion Analysis Systems}

Global positioning systems (GPS) have been increasingly studied in recent years for player tracking $[64,65,67,85]$. This tracking allows for movement analysis on the field or court, which can be useful for female athletes who engage in sports that require running as the primary means of locomotion, along with change of direction. One challenge is that current technologies often limit the range of data collection based on wireless range capability, although quality data on athlete performance can still be tracked. For instance, Benjamin et al. report device biases of only $1.99 \pm 1.81 \%$ for $400 \mathrm{~m}$ running, $1.26 \pm 1.04 \%$ for $20 \mathrm{~m}$ linear running, and $1.80 \pm 1.93 \%$ for peak speed for one wearable GPS tracker [67]. Literature surrounding GPS systems in female sports includes topics such as distance traveled, training load, player load by position (among NCAA DI female soccer athletes), exercise energy expenditure, maximal speed, acceleration/deceleration, and duration of high-intensity running $[64,65,85,86]$. Among elite female field hockey players, it has been shown that different positions have varying physiological demands associated with frequency of high-intensity efforts and total distance covered. This has been shown in female volleyball [78] and soccer [65] athletes as well. In order to meet specific demands of each position, programming in S\&C should be individualized to the female athlete to match their specific position demands [87]. 
Recovery is also a crucial component for female athletes to maintain athletic performance. Suggestions in the literature have pointed to using distance tracking as a way to measure fatigue during matches, as this may influence different strategies for substitutions in team sports and may aid in injury prevention for injuries related to fatigue [86]. While S\&C coaches should remember to train a baseline or foundational movement pattern specific to the individual, research among South African semi-elite female soccer players suggests that training for specific positions within sport may increase athletic performance directly related to the female athlete's role in their sport [76]. However, caution should be taken when interpreting and applying these results to various age populations of female athletes. Sport specialization may negatively affect physical literacy but may also have a negative financial impact on one's family due to an increased potential for overuse injuries and healthcare costs [88].

GPS devices represent one of many options in the wearable technology field in sport and exercise. Their implementation is as simple as attaching a GPS device to the female athlete. The consumer market of wearable technology revolves, in part, around simplicity of use. This simplicity has driven the market for wearable technology upwards and has expanded its reach. Other examples of wearable technologies within the literature among female athletes include heart rate (HR) monitors to measure variables such as training load or HRV and corroborate RPE with physical performance $[64,73,85]$. Non-GPS movement-based wearables are also available that can track accelerations, decelerations, jumps, and changes in direction $[74,78]$. Such devices provide greater reliability when used indoors and rely on gyroscopes, magnetometers, and accelerometers rather than communication between multiple GPS satellites. These microsensor technologies have been used to longitudinally determine player loads during competition by position and game outcome among NCAA DI female basketball players [74], as well as player load, high-impact player load, explosive efforts, and jumps among NCAA DI female volleyball players [78]. The use of wearable technology for exercise to meet the American College of Sports Medicine's (ACSM) weekly exercise recommendations has also been shown to increase adherence to exercise programs [89]. Many of these devices in the literature are wrist-worn devices, which may aid in adherence when using these wearables due to their ease of use. In these ways, wearable devices can provide normative data and/or real-time monitoring to observe training and competition session loads and track recovery, and ultimately enhance athletic performance $[73,74,78]$.

\subsection{Sleep Monitoring}

Sleep has widely been known to influence athletic performance. Wearable and sheettype devices have allowed for monitoring of sleep habits, which may provide more data to support sleep patterns and their influence on training and performance [71]. Heart rate variability (HRV), or the time between heartbeats, has been studied as a means of assessing cardiac health and the state of one's autonomic nervous system (ANS), which aids in regulating cardiac activity $[77,90]$. Female cyclists competing in the Tour de France showed that HRV indices increased over days correlated with increased load within the race. Interestingly, these female cyclists also showed that one week of recovery postrace was necessary to return heart-rate variability to pre-race values [66]. Among highlevel female soccer players, disrupted individual sleep patterns were identified in that HRV differed among individuals and training loads. In this case, as well as in female intercollegiate middle-distance runners, higher workloads were associated with more sleep disruptions [68,71]. In terms of changing or improving sleep patterns, a study among female African-American college students revealed that stand-alone wearable technologies for sleep showed no effect in improving sleep [91]. This suggests that wearable technologies for sleep may be best implemented to track sleep data, but the technology may not be the best method for changing sleep habits.

In another study among high-level female soccer athletes, it was suggested that tracking both subjective and objective sleep measurements, such as perceived sleep quality 
and waking HRV measures, respectively, may allow coaches to make informed decisions on load management or fatigue in female athletes [70]. Such observations of load management and fatigue were trialed by Tian et al., who utilized HRV measurements at night before sleep to identify functional overreaching and nonfunctional overreaching states among elite female wrestlers [77]. While some measures of HRV can be costly to implement, some research is beginning to emerge using smartphone applications for recording HRV and may be useful in monitoring the effects from training for female athletes in a team sport [69]. Future research should aim to explore the benefits of implementing sleep data from wearable technology in adjusting sleep habits for female athletes who do not receive 7-8 h of undisturbed sleep.

In general, technologies in sports used to monitor various elements of training and recovery, such as training velocity, motion analysis, and sleep quality, have gathered a considerable amount of attention in the sport and exercise science fields. We acknowledge the obvious breadth of this section and only provide an extremely brief overview of contemporary uses of technology in S\&C practices with female athletes. Understandably, this section could be expanded into its own review, or several reviews, and the larger S\&C literature would be greatly benefited by additional in-depth reviews of subtopics presented here. The future of technology in sport is likely to continue on an upward trend with the advancement of technology. As the market for wearable devices continues to increase, the inclusion of female athletes into the scientific literature on wearable technology should grow similarly.

\section{Conclusions}

The growth in female participation in sport has increased immensely and it is time for the scientific literature to catch up with the upward trend in female participation. Performance in elite levels of competition was not as widely available or part of programming for the female athlete prior to Title IX. The passage of Title IX in 1972 created a pivotal shift towards the inclusion of females in both sport and S\&C. The increase in participation is evident in the inclusion of females in competitive sports from youth levels to the Olympic and Paralympic Games. The 1989 position statement from the NSCA summarized their recommendations on training the female athlete by stating that "males and females should train for strength in the same basic way, employing similar methodologies, programs, and types of exercises" (p. 30) [92]. Thirty years after the NSCA's position statement, in 2018, a narrative review concluded that the NSCA's recommendation from 1989 still holds true [93].

BFR training may have implications for female athletes, especially when the training goals involve return-to-play after injury. The addition of BFR training in female athletes after injury may aid in their ability to combat muscle atrophy by promoting muscle growth under lighter loads. Functional screening is an important aspect of the S\&C coaches' program as well, and $S \& C$ coaches should use a broad approach to assess, screen, and analyze movement holistically, rather than rely on one single movement assessment. Additionally, the incorporation of neuromuscular training for the lower extremity may aid in injury prevention for the female athlete through improved joint awareness and postural control. Sports technology may also continue to grow in popularity and utility among female athletes. Sports technology may aid in tracking and monitoring specific training and physiologic data such as barbell velocity, sleep quality, and HRV. Use of technology in sports may also aid in developing or modifying performance measures to better characterize athletic abilities in female athletes beyond previously used tests [75]. This data may also aid the S\&C coach in implementing and/or adjusting programs to improve the female athlete's performance and recovery. The common thread among all three current topics presented in this review is a lack of inclusion of females in the sport and exercise science literature. As these current trends continue to grow and as new trends begin to emerge within the sports and exercise science community, the inclusion of female athletes in the scientific literature should be emphasized. 
Narrative reviews are not without their limitations. This review examined the literature through a narrative rather than a strictly systematic lens. Systematic reviews offer a broad summary of the literature using explicit and reproducible methods to comprehensively search, critique, and synthesize research on a specific topic or issue [94]. Whereas systematic reviews may also include a meta-analysis of statistical data, a narrative review lacks this analysis of data, but still offers an opportunity for synthesis of available literature. Furthermore, a second limitation of this study is that the inclusion of females in the literature is low. Therefore, the available literature to be synthesized is of lower quantity compared to that of men. The lower quantity of literature available also serves to highlight the need for the inclusion of females as research participants. The literature surrounding BFR and athletic performance is inherently low in quantity as well. Synthesizing recommendations for athletic performance improvements using BFR training from study populations that fail to include athletic females provides a disservice to this population. Future research should aim to further analyze the gap in BFR training for female athletes in improving athletic performance. Additionally, functional assessment must first start with either a screen or assessment of functional movement or capacity of the individual. Future research on functional screening should aim to evaluate the conjunction of multiple different screening and assessment tools in their ability to predict injury in female athletes. Finally, limitations also exist in the available literature on the role of technology in sports for female athletes. Future research should work to increase understanding of how various technologies could benefit female athletes in S\&C and sports.

Author Contributions: Conceptualization, T.J.T. and D.K.B.; methodology, A.C.S., T.J.T. and D.K.B.; software, A.C.S.; validation, A.C.S.; formal analysis, A.C.S. and T.J.T.; investigation, A.C.S. and T.J.T.; data curation, A.C.S.; writing-original draft preparation, A.C.S., T.J.T. and D.K.B.; writing-review and editing, A.C.S. and D.K.B.; visualization, A.C.S. and T.J.T.; supervision, A.C.S. and D.K.B.; project administration, A.C.S. and D.K.B. All authors have read and agreed to the published version of the manuscript.

Funding: This research received no external funding.

Institutional Review Board Statement: Not applicable.

Informed Consent Statement: Not applicable.

Data Availability Statement: No new data were created or analyzed in this study. Data sharing is not applicable to this article.

Conflicts of Interest: The authors declare no conflict of interest.

\section{References}

1. Kaestner, R.; Xu, X. Title IX, girls' sports participation, and adult female physical activity and weight. Eval. Rev. 2010, 34, 52-78. [CrossRef]

2. Shurley, J.; Felkar, V.; Greviskes, L.; Todd, J. Historical and Social Considerations of Strength Training for Female Athletes. Strength Cond. J. 2020, 42, 22-35. [CrossRef]

3. Antunovic, D. “Just Another Story": Sports Journalists' Memories of Title IX and Women's Sport. Commun. Sport 2015, 5, 205-225. [CrossRef]

4. International Olympic Committee. Factsheet: Women in the Olympic Movement; International Olympic Committee: Lausanne, Switzerland, 2020.

5. $\quad$ Reynolds, M.L.; Ransdell, L.B.; Lucas, S.M.; Petlichkoff, L.M.; Gao, Y. An examination of current practices and gender differences in strength and conditioning in a sample of varsity high school athletic programs. J. Strength Cond. Res. 2012, 26, 174-183. [CrossRef]

6. Costello, J.T.; Bieuzen, F.; Bleakley, C.M. Where are all the female participants in Sports and Exercise Medicine research? Eur. J. Sport Sci. 2014, 14, 847-851. [CrossRef]

7. Barrett Holloway, J.; Gater, D.; Ritchie, M.; Gilstrap, L.; Stoessel, L.; Todd, J.; Kontor, K.; Todd, T.; Gater, D.; Hillman, S.; et al. Strength Training for Female Athletes: A Position Paper: Part I. Natl. Strength Cond. Assoc. J. 1989, 11, 43-51. [CrossRef]

8. Todd, J.; Lovett, D.; Todd, T. Survey: The status of women in the strength and conditioning profession. Natl. Strength Cond. Assoc. J. 1991, 13, 35-38. [CrossRef] 
9. Laskowski, K.D.; Ebben, W.P. Profile of Women Collegiate Strength and Conditioning Coaches. J. Strength Cond. Res. 2016, 30, 3481-3493. [CrossRef]

10. Magnusen, M.J.; Rhea, D.J. Division I athletes' attitudes toward and preferences for male and female strength and conditioning coaches. J. Strength Cond. Res. 2009, 23, 1084-1090. [CrossRef]

11. American College of Sports Medicine. Advanced Search Builder. Available online: https://journals.lww.com/acsm-msse/pages/ advancedsearch.aspx (accessed on 28 January 2022).

12. National Strength and Conditioning Association. Advanced Search Builder. Available online: https://journals.lww.com/nscajscr/pages/advancedsearch.aspx (accessed on 28 January 2022).

13. Scott, B.R.; Loenneke, J.P.; Slattery, K.M.; Dascombe, B.J. Exercise with blood flow restriction: An updated evidence-based approach for enhanced muscular development. Sports Med. 2015, 45, 313-325. [CrossRef]

14. Loenneke, J.P.; Fahs, C.A.; Rossow, L.M.; Abe, T.; Bemben, M.G. The anabolic benefits of venous blood flow restriction training may be induced by muscle cell swelling. Med. Hypotheses 2012, 78, 151-154. [CrossRef]

15. Bowman, E.N.; Elshaar, R.; Milligan, H.; Jue, G.; Mohr, K.; Brown, P.; Watanabe, D.M.; Limpisvasti, O. Proximal, Distal, and Contralateral Effects of Blood Flow Restriction Training on the Lower Extremities: A Randomized Controlled Trial. Sports Health 2019, 11, 149-156. [CrossRef]

16. Sato, Y. The history and future of KAATSU Training. Int. J. KAATSU Train. Res. 2005, 1, 1-5. [CrossRef]

17. Counts, B.R.; Rossow, L.M.; Mattocks, K.T.; Mouser, J.G.; Jessee, M.B.; Buckner, S.L.; Dankel, S.J.; Loenneke, J.P. Let's talk about sex: Where are the young females in blood flow restriction research? Clin. Physiol. Funct. Imaging 2018, 38, 1-3. [CrossRef]

18. Neto, G.R.; Novaes, J.S.; de Araújo Júnior, A.T.; Silva, J.C.G.; Souza, R.P.; Cirilo-Sousa, M.S. Hemodynamic responses to strength exercise with blood flow restriction during different phases of the menstrual cycle. Motricidade 2017, 13, 31-40. [CrossRef]

19. Scott, B.R.; Peiffer, J.J.; Thomas, H.J.; Marston, K.J.; Hill, K.D. Hemodynamic Responses to Low-Load Blood Flow Restriction and Unrestricted High-Load Resistance Exercise in Older Women. Front. Physiol. 2018, 9, 1324. [CrossRef]

20. Kim, E.; Gregg, L.D.; Kim, L.; Sherk, V.D.; Bemben, M.G.; Bemben, D.A. Hormone responses to an acute bout of low intensity blood flow restricted resistance exercise in college-aged females. J. Sports Sci. Med. 2014, 13, 91-96.

21. Neto, G.R.; Sousa, M.S.C.; Silva, G.V.E.; Gil, A.L.S.; Salles, B.F.; Novaes, J.S. Acute resistance exercise with blood flow restriction effects on heart rate, double product, oxygen saturation and perceived exertion. Clin. Physiol. Funct. Imaging 2016, 36, 53-59. [CrossRef]

22. Amani-Shalamzari, S.; Rajabi, S.; Rajabi, H.; Gahreman, D.E.; Paton, C.; Bayati, M.; Rosemann, T.; Nikolaidis, P.T.; Knechtle, B. Effects of Blood Flow Restriction and Exercise Intensity on Aerobic, Anaerobic, and Muscle Strength Adaptations in Physically Active Collegiate Women. Front. Physiol. 2019, 10, 810. [CrossRef]

23. Araujo, C.; Neto, G.R.; Cirilo-Sousa, M.S.; Chaves, E.; Brown, A.; Dias, I.; Sa, M.; Vianna, J.; Novaes, J.S. Chronic Effects of Resistance Training with Blood Flow Restriction on Maximal Dynamic Strength and Flexibility at Different Phases of the Menstrual Cycle. J. Exerc. Physiol. Online 2017, 20, 117-128.

24. Centner, C.; Ritzmann, R.; Gollhofer, A.; König, D. Effects of Whole-Body Vibration Training and Blood Flow Restriction on Muscle Adaptations in Women: A Randomized Controlled Trial. J. Strength Cond. Res. 2020, 34, 603-608. [CrossRef] [PubMed]

25. Letieri, R.V.; Teixeira, A.M.; Furtado, G.E.; Lamboglia, C.G.; Rees, J.L.; Gomes, B.B. Effect of 16 weeks of resistance exercise and detraining comparing two methods of blood flow restriction in muscle strength of healthy older women: A randomized controlled trial. Exp. Gerontol. 2018, 114, 78-86. [CrossRef]

26. Manimmanakorn, A.; Hamlin, M.J.; Ross, J.J.; Taylor, R.; Manimmanakorn, N. Effects of low-load resistance training combined with blood flow restriction or hypoxia on muscle function and performance in netball athletes. J. Sci. Med. Sport 2013, 16, 337-342. [CrossRef] [PubMed]

27. Rawska, M.; Gepfert, M.; Mostowik, A.; Krzysztofik, M.; Wojdala, G.; Lulinska, A.; Wilk, M. Does blood flow restriction influence the maximal number of repetitions performed during the bench press? A pilot study. Balt. J. Health Phys. Act. 2019, 11, 9-17. [CrossRef]

28. Yasuda, T.; Fukumura, K.; Iida, H.; Nakajima, T. Effects of detraining after blood flow-restricted low-load elastic band training on muscle size and arterial stiffness in older women. Springerplus 2015, 4, 348. [CrossRef]

29. Vogel, J.; Niederer, D.; Engeroff, T.; Vogt, L.; Troidl, C.; Schmitz-Rixen, T.; Banzer, W.; Troidl, K. Effects on the profile of circulating miRNAs after single bouts of resistance training with and without blood flow restriction-A three-arm, randomized crossover trial. Int. J. Mol. Sci. 2019, 20, 3249. [CrossRef]

30. Patterson, S.D.; Hughes, L.; Warmington, S.; Burr, J.; Scott, B.R.; Owens, J.; Abe, T.; Nielsen, J.L.; Libardi, C.A.; Laurentino, G.; et al Blood flow restriction exercise: Considerations of methodology, application, and safety. Front. Physiol. 2019, 10, 1-15. [CrossRef]

31. Patterson, S.D.; Ferguson, R.A. Increase in calf post-occlusive blood flow and strength following short-term resistance exercise training with blood flow restriction in young women. Eur. J. Appl. Physiol. 2010, 108, 1025-1033. [CrossRef]

32. Cook, G.; Burton, L.; Hoogenboom, B.J.; Voight, M. Functional movement screening: The use of fundamental movements as an assessment of function-Part 2. Int. J. Sports Phys. Ther. 2014, 9, 549-563.

33. Benis, R.; Bonato, M.; La Torre, A. Elite female basketball players' body-weight neuromuscular training and performance on the Y-Balance Test. J. Athl. Train. 2016, 51, 688-695. [CrossRef]

34. Brumitt, J.; Heiderscheit, B.; Manske, R.C.; Niemuth, P.E.; Mattocks, A.; Rauh, M. Preseason Functional Test Scores Are Associated with Future Sports Injury in Female Collegiate Athletes. J. Strength Cond. Res. 2018, 32, 1692-1701. [CrossRef] [PubMed] 
35. Clay, H.; Mansell, J.; Tierney, R. Association between rowing injuries and the Functional Movement Screen ${ }^{\mathrm{TM}}$ in female collegiate Division I rowers. Int. J. Sports Phys. Ther. 2016, 11, 345-349. [PubMed]

36. Dorrel, B.; Long, T.; Shaffer, S.; Myer, G.D. The functional movement screen as a predictor of injury in national collegiate athletic association division II athletes. J. Athl. Train. 2018, 53, 29-34. [CrossRef] [PubMed]

37. Landis, S.E.; Baker, R.T.; Seegmiller, J.G. Non-contact anterior cruciate ligament and lower extremity injury risk prediction using functional movement screen and knee abduction moment: An epidemiological observation of female intercollegiate athletes. Int. J. Sports Phys. Ther. 2018, 13, 973-984. [CrossRef]

38. Ness, B.M.; Comstock, B.A.; Schweinle, W.E. Changes in Dynamic Balance and Hip Strength After an Eight-Week Conditioning Program in Ncaa Division I Female Soccer (Football) Athletes. Int. J. Sports Phys. Ther. 2016, 11, 1054-1064.

39. Šiupšinskas, L.; Garbenytė-Apolinskienė, T.; Salatkaitè, S.; Gudas, R.; Trumpickas, V. Association of pre-season musculoskeletal screening and functional testing with sports injuries in elite female basketball players. Sci. Rep. 2019, 9, 9286. [CrossRef]

40. Sprague, P.A.; Mokha, G.M.; Gatens, D.R. Changes in Functional Movement Screen Scores Over a Season in Collegiate Soccer and Volleyball Athletes. J. Strength Cond. Res. 2014, 28, 3155-3163. [CrossRef]

41. Stapleton, D.T.; Boergers, R.J.; Rodriguez, J.; Green, G.; Johnson, K.; Williams, P.; Leelum, N.; Jackson, L.; Vallorosi, J. The Relationship Between Functional Movement, Dynamic Stability, and Athletic Performance Assessments in Baseball and Softball Athletes. J. Strength Cond. Res. 2021, 35, S42-S50. [CrossRef]

42. Walbright, P.D.; Walbright, N.; Ojha, H.; Davenport, T. Validity of functional screening tests to predict lost-time lower quarter injury in a cohort of female collegiate athletes. Int. J. Sports Phys. Ther. 2017, 12, 948-959. [CrossRef]

43. Warren, M.; Smith, C.A.; Chimera, N.J. Association of the functional movement screen with injuries in division I athletes. J. Sport Rehabil. 2015, 24, 163-170. [CrossRef]

44. Warren, M.; Lininger, M.R.; Smith, C.A.; Copp, A.J.; Chimera, N.J. Association of functional screening tests and noncontact injuries in division I women student-athletes. J. Strength Cond. Res. 2020, 34, 2302-2311. [CrossRef]

45. Zibaie, A.; Sheikhhoseini, R.; Babakhani, F. Relationships of the functional movement screen test with the proprioception of the core and anthropometric characteristics in female athletes. J. Clin. Res. Paramed. Sci. 2019, 8, 1-5. [CrossRef]

46. Zuckerman, S.L.; Wegner, A.M.; Roos, K.G.; Djoko, A.; Dompier, T.P.; Kerr, Z.Y. Injuries sustained in National Collegiate Athletic Association men's and women's basketball, 2009/2010-2014/2015. Br. J. Sports Med. 2018, 52, 261-268. [CrossRef]

47. Cook, G.; Burton, L.; Hoogenboom, B.J.; Voight, M. Functional movement screening: The use of fundamental movements as an assessment of function-Part 1. Int. J. Sports Phys. Ther. 2014, 9, 396-409.

48. Lockie, R.; Schultz, A.; Callaghan, S.; Jordan, C.; Luczo, T.; Jeffriess, M. A preliminary investigation into the relationship between functional movement screen scores and athletic physical performance in female team sport athletes. Biol. Sport 2015, 32, 41-51. [CrossRef]

49. Cook, G.; Burton, L.; Hoogenboom, B. Pre-participation screening: The use of fundamental movements as an assessment of function-Part 1. N. Am. J. Sport. Phys. Ther. 2006, 1, 62-72.

50. Chorba, R.S.; Chorba, D.J.; Bouillon, L.E.; Overmyer, C.A.; Landis, J.A. Use of a functional movement screening tool to determine injury risk in female collegiate athletes. N. Am. J. Sport. Phys. Ther. 2010, 5, 47-54.

51. Kodesh, E.; Shargal, E.; Kislev-Cohen, R.; Funk, S.; Dorfman, L.; Samuelly, G.; Hoffman, J.R.; Sharvit, N. Examination of the Effectiveness of Predictors for Musculoskeletal Injuries in Female Soldiers. J. Sports Sci. Med. 2015, 14, 515-521.

52. Clausen, M.B.; Tang, L.; Zebis, M.K.; Krustrup, P.; Hölmich, P.; Wedderkopp, N.; Andersen, L.L.; Christensen, K.B.; Møller, M.; Thorborg, K. Self-reported previous knee injury and low knee function increase knee injury risk in adolescent female football. Scand. J. Med. Sci. Sport. 2016, 26, 919-926. [CrossRef]

53. Faude, O.; Junge, A.; Kindermann, W.; Dvorak, J. Risk factors for injuries in elite female soccer players. Br. J. Sports Med. 2006, 40, 785-790. [CrossRef]

54. Boucher, B.; Rich, A.; Gobert, D.; Gardner, B.; Metzner, P.; King, C.; Buse, M. The Effectiveness of a Functional Movement Assessment and 4-Week Exercise Training Program for Female High School Athletes. J. Strength Cond. Res. 2021, 35, 102-110. [CrossRef]

55. Prodromos, C.C.; Han, Y.; Rogowski, J.; Joyce, B.; Shi, K. A meta-analysis of the incidence of anterior cruciate ligament tears as a function of gender, sport, and a knee injury-reduction regimen. Arthroscopy 2007, 23, 1320-1325.e6. [CrossRef]

56. Hewett, T.E.; Myer, G.D.; Ford, K.R.; Heidt, R.S., Jr.; Colosimo, A.J.; McLean, S.G.; van den Bogert, A.J.; Paterno, M.V.; Succop, P. Biomechanical measures of neuromuscular control and valgus loading of the knee predict anterior cruciate ligament injury risk in female athletes: A prospective study. Am. J. Sports Med. 2005, 33, 492-501. [CrossRef]

57. Padua, D.A.; Marshall, S.W.; Boling, M.C.; Thigpen, C.A.; Garrett, W.E., Jr.; Beutler, A.I. The Landing Error Scoring System (LESS) is a valid and reliable clinical assessment tool of jump-landing biomechanics: The JUMP-ACL study. Am. J. Sports Med. 2009, 37, 1996-2002. [CrossRef] [PubMed]

58. Wesley, C.A.; Aronson, P.A.; Docherty, C.L. Lower extremity landing biomechanics in both sexes after a functional exercise protocol. J. Athl. Train. 2015, 50, 914-920. [CrossRef] [PubMed]

59. Greenberg, E.T.; Barle, M.; Glassman, E.; Jacob, L.; Jaafar, H.; Johnson, A.; Layug, N.; Rollo, E.; Jung, M.-K. Reliability and stability of the Y Balance Test in healthy early adolescent female athletes. Orthop. J. Sport. Med. 2019, 7, 1-6. [CrossRef]

60. Cook, G.; Plisky, P. YBT Online Manual V1. Functional Movement Systems 2010. pp. 1-32. Available online: https://www. functionalmovement.com/files / Articles/660a_YBT\%20Online\%20Manual\%20v1.pdf (accessed on 28 January 2022). 
61. Bulow, A.; Anderson, J.E.; Leiter, J.R.; MacDonald, P.B.; Peeler, J. The Modified Star Excursion Balance and Y-Balance Test results differ when assessing physically active healthy adolescent females. Int. J. Sports Phys. Ther. 2019, 14, 192-203. [CrossRef]

62. Bulow, A.; Bellemare, A.; Anderson, J.E.; Leiter, J.R.S.; MacDonald, P.B.; Peeler, J.D. Lower extremity kinematics of the Y-Balance Test in healthy and ACL injured adolescent females. Int. J. Sports Phys. Ther. 2021, 16, 381-392. [CrossRef]

63. Kramer, T.A.; Sacko, R.S.; Pfeifer, C.E.; Gatens, D.R.; Goins, J.M.; Stodden, D.F. The association between the Functional Movement Screen ${ }^{\mathrm{TM}}$, Y-Balance Test, and physical performance tests in male and female high school athletes. Int. J. Sports Phys. Ther. 2019, 14, 911-919. [CrossRef]

64. Bozzini, B.N.; McFadden, B.A.; Scruggs, S.K.; Arent, S.M. Evaluation of Performance Characteristics and Internal and External Training Loads in Female Collegiate Beach Volleyball Players. J. Strength Cond. Res. 2021, 35, 1559-1567. [CrossRef]

65. Kupperman, N.; DeJong, A.F.; Alston, P.; Hertel, J.; Saliba, S.A. Athlete workloads during Collegiate Women's Soccer practice: Implications for return to play. J. Athl. Train. 2021, 56, 321-330. [CrossRef] [PubMed]

66. Barrero, A.; Schnell, F.; Carrault, G.; Kervio, G.; Matelot, D.; Carré, F.; Le Douairon Lahaye, S. Daily fatigue-recovery balance monitoring with heart rate variability in well-trained female cyclists on the Tour de France circuit. PLoS ONE 2019, 14, e0213472. [CrossRef] [PubMed]

67. Benjamin, C.L.; Hosokawa, Y.; Curtis, R.M.; Schaefer, D.A.; Bergin, R.T.; Abegg, M.R.; Casa, D.J. Environmental Conditions, Preseason Fitness Levels, and Game Workload: Analysis of a Female NCAA DI National Championship Soccer Season. J. Strength Cond. Res. 2020, 34, 988-994. [CrossRef] [PubMed]

68. Costa, J.A.; Figueiredo, P.; Nakamura, F.Y.; Rebelo, A.; Brito, J. Monitoring individual sleep and nocturnal heart rate variability indices: The impact of training and match schedule and load in high-level female soccer players. Front. Physiol. 2021, 12, 533. [CrossRef]

69. Flatt, A.A.; Esco, M.R. Evaluating individual training adaptation with smartphone-derived heart rate variability in a collegiate female soccer team. J. Strength Cond. Res. 2016, 30, 378-385. [CrossRef]

70. Flatt, A.A.; Esco, M.R.; Nakamura, F.Y. Individual heart rate variability responses to preseason training in high level female soccer players. J. Strength Cond. Res. 2017, 31, 531-538. [CrossRef]

71. Hoshikawa, M.; Suzuki, Y.; Oriishi, M. Effects of Normobaric Hypoxia Equivalent to 2,000-m Altitude on Sleep and Physiological Conditions of Athletes: A Study Using Sheet-Type Sensor. J. Strength Cond. Res. 2013, 27, 2309-2313. [CrossRef]

72. McKeown, I.; Chapman, D.W.; Taylor, K.L.; Ball, N.B. Time Course of Improvements in Power Characteristics in Elite Development Netball Players Entering a Full-Time Training Program. J. Strength Cond. Res. 2016, 30, 1308-1315. [CrossRef]

73. Perrotta, A.S.; Taunton, J.E.; Koehle, M.S.; White, M.D.; Warburton, D.E.R. Monitoring the Prescribed and Experienced Heart Rate-Derived Training Loads in Elite Field Hockey Players. J. Strength Cond. Res. 2019, 33, 1394-1399. [CrossRef]

74. Ransdell, L.B.; Murray, T.; Gao, Y.; Jones, P.; Bycura, D. A 4-Year Profile of Game Demands in Elite Women's Division I College Basketball. J. Strength Cond. Res. 2020, 34, 632-638. [CrossRef]

75. Sekulic, D.; Krolo, A.; Spasic, M.; Uljevic, O.; Peric, M. The Development of a New Stop'n'go Reactive-Agility Test. J. Strength Cond. Res. 2014, 28, 3306-3312. [CrossRef]

76. Strauss, A.; Sparks, M.; Pienaar, C. The use of GPS analysis to quantify the internal and external match demands of semi-elite level female soccer players during a tournament. J. Sports Sci. Med. 2019, 18, 73-81.

77. Tian, Y.; He, Z.; Zhao, J.; Tao, D.; Xu, K.; Earnest, C.P.; Mc Naughton, L.R. Heart Rate Variability Threshold Values for EarlyWarning Nonfunctional Overreaching in Elite Female Wrestlers. J. Strength Cond. Res. 2013, 27, 1511-1519. [CrossRef]

78. Vlantes, T.G.; Readdy, T. Using microsensor technology to quantify match demands in collegiate women's volleyball. J. Strength Cond. Res. 2017, 31, 3266-3278. [CrossRef]

79. Weakley, J.; Mann, B.; Banyard, H.; Mc Laren, S.; Scott, T.; Garcia-Ramos, A. Velocity-based training: From theory to application. Strength Cond. J. 2021, 43, 31-49. [CrossRef]

80. Torrejón, A.; Balsalobre-Fernández, C.; Haff, G.G.; García-Ramos, A. The load-velocity profile differs more between men and women than between individuals with different strength levels. Sport. Biomech. 2018, 18, 245-255. [CrossRef]

81. Torrejón, A.; Janicijevic, D.; Haff, G.G.; Garcia-Ramos, A. Acute effects of different set configurations during a strength-oriented resistance training session on barbell velocity and the force-velocity relationship in resistance-trained males and females. Eur. $J$. Appl. Physiol. 2019, 119, 1409-1417. [CrossRef]

82. Guerriero, A.; Varalda, C.; Piacentini, M.F. The role of velocity based training in the strength periodization for modern athletes. $J$. Funct. Morphol. Kinesiol. 2018, 3, 55. [CrossRef]

83. González-Badillo, J.J.; Rodriguez-Rosell, D.; Sánchez-Medina, L.; Gorostiaga, E.M.; Pareja-Blanco, F. Maximal intended velocity training induces greater gains in bench press performance than deliberately slower half-velocity training. Eur. J. Sport Sci. 2014, 14, 772-781. [CrossRef]

84. Dai, B.; Layer, J.; Vertz, C.; Hinshaw, T.; Cook, R.; Li, Y.; Sha, Z. Baseline Assessments of Strength and Balance Performance and Bilateral Asymmetries in Collegiate Athletes. J. Strength Cond. Res. 2019, 33, 3015-3029. [CrossRef]

85. Bozzini, B.N.; McFadden, B.A.; Walker, A.J.; Arent, S.M. Varying Demands and Quality of Play Between In-Conference and Out-of-Conference Games in Division I Collegiate Women's Soccer. J. strength Cond. Res. 2020, 34, 3364-3368. [CrossRef]

86. Hodun, M.; Clarke, R.; De Ste Croix, M.B.; Hughes, J.D. Global Positioning System analysis of running performance in female field sports: A review of the literature. Strength Cond. J. 2016, 38, 49-56. [CrossRef] 
87. Gabbett, T.J. GPS analysis of elite women's field hockey training and competition. J. Strength Cond. Res. 2010, $24,1321-1324$. [CrossRef]

88. Bell, D.R.; DiStefano, L.; Pandya, N.K.; McGuine, T.A. The public health consequences of sport specialization. J. Athl. Train. 2019, 54, 1013-1020. [CrossRef]

89. McFadden, C. Wearable exercise technology and the impact on college women's physical activity. Quest 2021, 73, 179-191. [CrossRef]

90. Rajendra Acharya, U.; Paul Joseph, K.; Kannathal, N.; Lim, C.M.; Suri, J.S. Heart rate variability: A review. Med. Biol. Eng. Comput. 2006, 44, 1031-1051. [CrossRef]

91. Melton, B.F.; Buman, M.P.; Vogel, R.L.; Harris, B.S.; Bigham, L.E. Wearable devices to improve physical activity and sleep: A randomized controlled trial of college-aged African American women. J. Black Stud. 2016, 47, 610-625. [CrossRef]

92. Barrett Holloway, J.; Gater, D.; Ritchie, M.; Gilstrap, L.; Stoessel, L.; Todd, J.; Kontor, K.; Todd, T.; Gater, D.; Hillman, S.; et al. Strength training for female athletes: A position paper: Part II. Natl. Strength Cond. Assoc. J. 1989, 11, 29-36. [CrossRef]

93. Shurley, J.; Todd, J. Thirty years on: A narrative review of research on strength training for female athletes since the national strength and conditioning association's position paper. J. Kinesiol. Wellness 2018, 7, 46-72.

94. Gopalakrishnan, S.; Ganeshkumar, P. Systematic reviews and meta-analysis: Understanding the best evidence in primary healthcare. J. Fam. Med. Prim. Care 2013, 2, 9-14. [CrossRef] 